\title{
F" MSSTER
}

THE FUTURE ROLE OF GEOPRESSURED RESOURCES IN U.S. ENERGY POLICY (A SCENARIO APPROACH AND ANALYSIS)

Final Report, July 1, 1978-March 31, 1979

By

William M. Brown

April 3, 1979

Work Performed Under Contract No. AC02-78ET 28474

Hudson Institute, Inc.

Croton-on-Hudson, New York

\section{U. S. DEPARTMENT OF ENERGY}




\section{DISCLAIMER}

Portions of this document may be illegible in electronic image products. Images are produced from the best available original document. 

HI - $2991-R R$

\title{
The Future Role of Geopressured Resources In U.S. Energy POLICY (A Scenario Approach and Analysis)
}

Final Report

for the Period July 1, 1978-March 31, 1979

\section{By}

William M. Brown, Ph.D (Principal Investigator)

\author{
HUDSON INSTITUTE, INC. \\ Quaker Ridge Road \\ Croton-on-Hud son \\ New York 10520
}

Apri1 3, 1979

Prepared ror

THIE U.S. BNIERGY RI:SI:ARCII ANII DIVVIIIOPMI:NT AIMINISTRATION

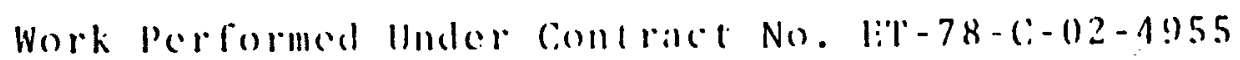


TABLE OF CONTENTS

LIST OI FIGURES . . . . . . . . . . . . . . . . iv

LIST OF TABLES . . . . . . . . . . . . . . . v v

ABSTRACT ..................... . $v i$

I. INTRODUCTION . . . . . . . . . . . . . . . 1

A. Historical Background . . . . . . . . . . . . . 1

B. The Relative Value of the Resource 3

II. THE ENERGY POTENTIAL OF THE GULF COAST

GEOPRESSURED ZONES . . . . . . . . . . . . . . . 7

A. The Resource Base . . . . . . . . . . 7

B. The Zones Between 20,000 and 30,000 Fect... 9

C. Zones Below 30,000 Feet ........... 11

III. THE GEOPRESSURED GEOTHERMAL RESOURCE, WORLDIIDE • • 17

IV. DEMAND PROJECTIONS FOR OIL AND GAS . . . . . . . . . 21

A. The Basic Scenario... . . . . . . . 25

V. THE POTENTIAL ROLE OF GEOPRESSURED ENERGY . . . . . 27

A. Economics of Geopressured Production . . . . . 27

B. Alternative Sources of Gas... . . . . . 28

1. Political pressures . . . . . . . . . 30

C. Future Gas Imports... . . . . . . . . . . 31

VI. GEOPRESSURED ENERGY DEVELOPMENT SCNEARIOS . . . . . 33

A. "Cautious Development" Scenario from
a Moderate Resource...... . . . . 33

B. Variations in the Ultimate Producible

c. Worldwide cicopressured zones (W(iz) . . . . . . . 39 
TABLE OF CONTENTS (Cont'd)

D. Accelerated GCCiz Development Scenario, lirom a Moderate Resource.......... . 40

E. GCGZ Min-Max Sconarios........... . 44

F. A Politically Important Scenario...... . 47

VII. EVALUATION . . . . . . . . . . . . . 51

A. About the Chances for Success . . . . . . 51

B. An Early Success Scenario . . . . . . . 52

C. Scenarios Involving Early Failure . . . . . 54

VIII. CONCLUSIONS . . . . . . . . . . . . . 57 


\section{LIST OF FIGURES}

1. A Conceptual Energy Cascade... . . . . . . 4

2. Solubility of Methanc in Fresh Water . . . . . 10

3. Production Potential of Saturated Brines . . . . . 12

4. Hypothetical Crude 0il Production Potential-From Saturated Brines... . . . . . . . . . . 13

5. Selected Abnormal Formation Pressure Data, On- and Offshore Europe............. 19

6. Estimated Range of Scenario Parameters Over Time (Conservation Factors and $0 i 1$ and Gas Fraction) . . 22

7. Projections of Energy Demand Relative to Average Economic Growth Rates for U.S. and World in Years 2000 and 2050 . . . . . . . . . . . . . . . 23

8. "Cautious Development" Scenario for GCGZ Production, and Alternatives for Non-U.S. WGZ Production . . . 38

9. Accelerated Development Scenario for WGZ . . . . . 43 


\section{LIST OF TABLES}

1. Some Iistimates of the Methane Resource Base in the GCGZ . . . . . . . . . . . . . . . 8

2. Natural Gas l'roduction from the Gulf Coast Geopressured Zones, Cautious Development

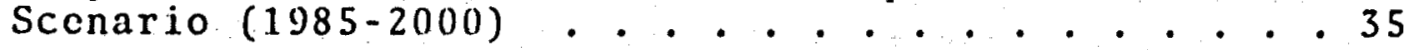

3. Accelerated Development of the GCGZ (1985-2000) . . 41

4. Five Basic Scenarios for Discovery of Methane

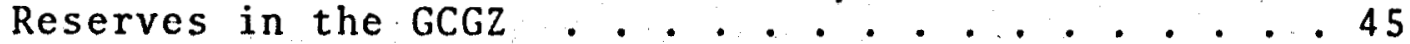




\begin{abstract}
The potential contribution of future gcopressured energy--especially methanc--to the U.S.' and the world's needs is cxamined through several scenarios. Although such production may not become competitive, if it does the eventual producible reserves from the Gulf Coast region seems likely to fall between 100 and 10,000 quads. The world's potential from similar resources is not known but may well be 10 times as great. The contribution to the projected future demand for hydrocarbons is found to become substantial in most of the success scenarios. The potential impact on fuel imports and their future prices is discussed. Although technical uncertainties are far too great at present for accurate projections, this could change rapidly as field data becomes available from DOE's $R$ \& $D$ program.
\end{abstract}




\section{I . INTRODUCTION}

\section{A. Historical Background}

For a two or threc ycar period following the Arab oil cmbargo the developed world felt itself strongly in the grip of the "energy crisis." A feeling closely akin to desperation existed about what the next decade or two might have in store. This was also a period in which the minds of U.S. scientists and engineers were being sharply turned toward the development of alternative cnergy sources. Almost every new energy development was seized upon by some of its advocates and promoters as a possible major contributor to a long-tcrm solution--if not, indeed, a panacea. One of these alternatives, the subject of this study, were the geopressured zones of the Gulf Coast (GCGZ) which had long been known to contain natural gas dissolved in hot water under great pressure.

These zones, along the coastline of Texas and Louisiana, became prominent after 1975, following a USGS report which suggested that they might contain, in place, 24,000 TCF of natural gas--the cquivalent of 4 trillion barrels of oil, rough1y twice the estimate of the ultimate world resources in petroleum.* Not only was this a fantastic estimate, but it was limited to onshore resources within a 60,000 square mile area and normal drilling depths--perhaps 10-20,000 feet. The USGS authors, a1so, extended their estimates by a factor of about three when both offshore and deeper zones were included. Thus they were suggesting the existence of about 72,000 TCF of methane, the equivalent of perhaps 12 trillion barrels of oil, although the amount which might be commercia11y extracted over time, if any, was highly debatable. Nevertheless, the cnormous potential of the GC. could clearly be visualized as producible at "some price" and carly cstimates had suggested that a price of about $\$ 2$ per MCF in 1974 dollars might be feasible. Secondly, two additional forms of energy were potentially available in the form of the heat and the mechanical energy stored in the hot highly-pressured fluid might also be significant. If fully exploited they could incrcase the available commercial energy by roughly a factor of two. Thus, it was simple to calculate that if 10 percent of the resource base could be eventually produced these zones might furnish about 15,000 quads of cnergy-enough to meet the present level of total U.S. demand for 200 years.

Sce article by Papadapoulous, et. al., in USGS Circular \#726, Nssessment of Ceothermal Resources of the United States-1975. Arefined, hut still chormons, estimate of theseresourecs appears also in an updated article hy R. Il. Wallace, ct. al., in a 1978 USGS Circular 11790 , with the same title. 
This astonishing story was almost too much to believe, and a great deal of skepticism soon settled about all facets of it. There was no question that the zones existed or that they contained the methane and the hot pressured fluids, but the quantities which existed or might be produced were "at tacked" as meaningless or exaggerated. Thus it has been estimated that the resource base is much smaller than that which the USGS had claimed in their 1975 document (Circular \#726), that there was likcly to be very fow reservoirs of sufficient size for commercial production, that the production costs from the better reservoirs might be over $\$ 5$ per MCF, that any practical uses of hot water would be a long time in arriving, and that large-scale production of fluids from the zones would be cnvironmentally dangerous--that it might cause substantial land subsidence or cven trigger earthquakcs, or both.

Since the arguments on both sides were extremely difficult to support adequately on a hypothetical basis a strong need arose for some field tests. The program to provide them has been and is now being sponsored by the Geothermal Energy Division of the DOE. Since this program started (its "start" is probably reasonably we 11 marked by the First Geothermal/Geopressurized Conference held in 1975) a few positive developments and concepts have emerged that appear to enhance the long-term prospects and at least partially counteract some of the negative assessments. One of these is the growing recognition that the GCGZ may not be unique. In fact, geopressured hydrocarbon resources appear to be relatively ubiquitous, worldwide. However, it is not at all clear to what extent any of them might be productive, or relatively productive when compared to the GCGZ. At this point in time it appears possible only to offer a very rough guess of the worldwide potential, namely, that to whatever extent the resources in the GCGZ prove to be commercial that over time similar resources throughout the rest of the world should eventually provide producible energy about 10 times as large (sec section III).

Second, while the professionals impatiently wait for actual measurements from the Brazoria well--the first well now being drilled to test directly the feasibility of finding, developing, and producing a geopressured reservoir--the earlier 1977 results from a well-of-opportunity (the Edna Del Cambre wel1 in Louisiana) indicated that in addition to the hoped-for dissolved methane some free gas might also be extracted. This unanticipated result created a bit of cxcitcment as it gave support to the optimistic speculation that most of the geopressured reservoirs might contain some frec gas in addition to dissolved methane. Moreover, it 
was believed possible that the producible amount of free gas might be greater than that of the dissolved gas--at least in many cases, since it was apparently true in the tho lidna nel Cambre zones tested. lirce gas in such amounts could drastically improve the economics of geopressured production.

Finally, the claim arose that it was also theoretically possible, at least over the long-term, that as technology enabled operators to completc productive wells at great depths, that the zones below 20,000 fect might become relatively prolific producers of methane, very-hot highly-pressured water, and--possibly--also some dissolved oil (this is discussed in Sections II-B,C). Both the producibility and the hydrocarbon contents of the very deep hot zones is open to much speculation, and will not be tested by the Brazoria we11. It is not unlikely, however, that through advantageous arrangements with private driliing contractors, other wel1s-of-opportunity may be tested before long that can supply some data which will permit a better assessment of this possibility. So sparse is the reliable information that each early bit of hard data could create a great swing in the assessment of the commercial potential of the GCGZ.

\section{B. The Relative Value of the Resources in the GCGZ}

Although the energy. in the GCGZ is known to be available in three forms (methanc, heat, and mechanical), in this study we will focus on the potential of the producible methane. We do so because it now seems apparent that the bulk of the commercial value of the producible energy will be associated with the methane. Thus, even though the heat content of the geopressured fluid might cxceed the amount of energy available from dissolved methanc, much of it may not be feasible to extract commercially for many years. The temperature of the fluid is generally too low for efficient production of electricity, and its usc as a direct source of heat is apt to be severely limited by a low level demand for moderately hot brine. Nevertheless, our current knowledge does not preclude the possibility that the anticipated availability of the hot brines in large quantities could inspirc a rapidly growing number of direct applications which, over time, might become surprisingly large. Certainly the potential for cascading these hot brines through multiple uses in industry and in nearby communities, as shown in figure 1 , is an attractive concept.

The potential for creating clectric power from both the heat and the mechanical cnergy of the geopressured fluid has 
Figure 1

A CONCEPTUAL ENERGY CASCADE

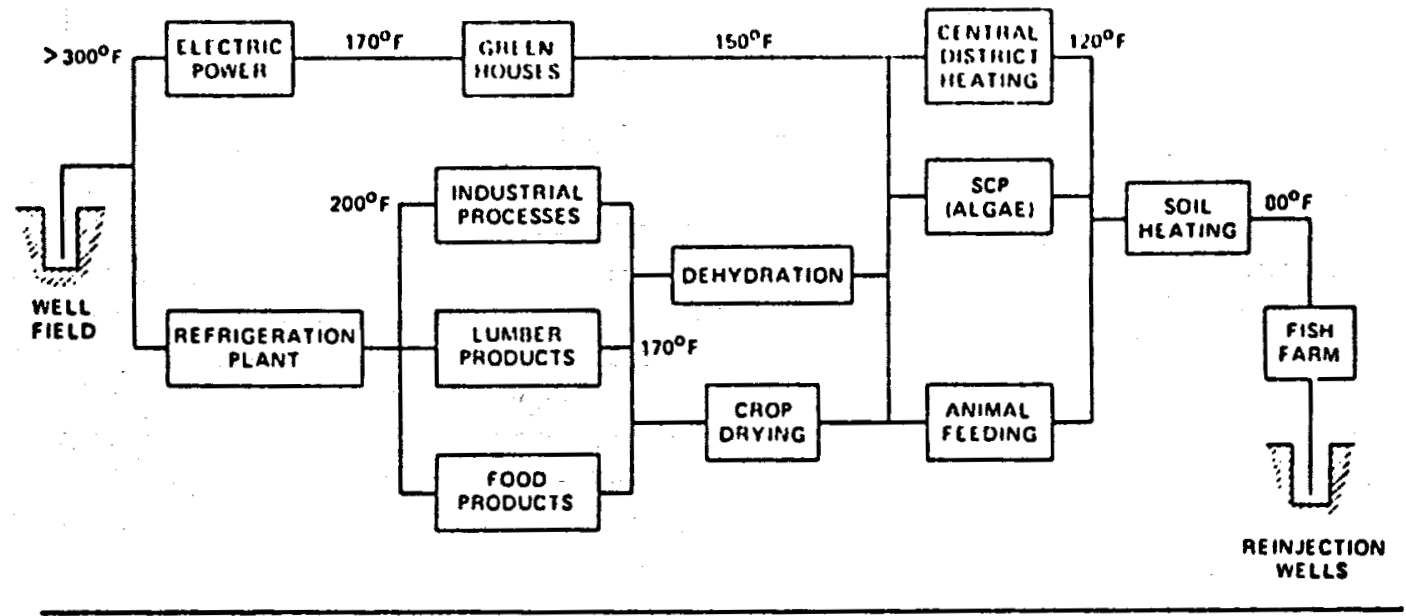

SOURCE: DAVID B. LOMBARD, "RESOURCE OEVELOPMENT/UTILIZATION: DEVELOPMENT AND UTILIZATION OF GEOPRESSURED GEOTHERMAL RESOURCES IN THE SOUTH-CENTRAL UNITED STATES," IN GEOLOGY OF ALTERNATE ENERGY RESOURCES IN THE SOUTH-CENTRAL UNITED STATES, ED. MICHAEL D. CAMPBELL (HOUSTON: HOUSTON GEOLOGTCAL SOCIETY, 1977), P. 291. 
received some added impetus from the development of the Total Flow concept by the Lawrence Livermore Laboratories, and more recently by their concept of the Velocity Pump Reaction Turbine.* These technologies are still not developed but hold promise for the future. Other approaches which are now being developed to furnish power from western hydrothermal reservoirs also should be adaptable to the GCGZ. The economics of any such applications, however, still remain to be demonstrated, a process which is likely to requiro $10-20$ years, Even if the geothermal power economics are unfavorable, the GCGZ might still be commercial just for the natural gas production. However, if they are favorable then the profits from the sale of the power can be considered as a reduction in the cost of producing the gas.

Because geopressured production of methane is considered likely to be more costly than the production of conventional natural gas, any profitable use of the hot water or the mechanical energy would improve the competitiveness of GCGZ methane. Over time we would cxpect the potential multiple uses of the hot fluids to increasc, and thereby enhance the overall economic potential. It may cventually also be possible for valuable minerals to be extracted from the brincs--although this is not now considered to be very promising. However, it is certainly satisfying to visualize the geopressured fluids fulfilling multiple industrial uses--and then porhaps used for local heating of homes, creating benign warm lakes, health spas, community swimming pools, and aquaculture farms--before they are run into the sea or reinjected into aquifers.

The possibility of avoiding the cost of reinjection by returning the geopressured fluids to the sea through surface canals, once their valuable contents have been extracted, is likely to depend--among other considerations--upon the ability of future technology to reduce any toxic boron concentrations to an environmentally acceptable level. Although it is not yet known how often boron levels will be too high or whether reducing them will become commercially feasible, projects are underway that hope to be able to develop a way to remove the boron inexpensively--for example, through ion exchange mechanisms. Whilc it may be optimistic to visualize these, as well as other required technologies, all developing satisfactorily in the near future, still with up to, say, 50 years to solve these problems what might appear optimistic today might not be unrealistic over that stretch of time. In the interim less efficient commercial approaches might be able to cxtract a large part of the potentially available energy.

*Sec lawrence livermore laboratorics report HUCRL,-52583

by $\Lambda$. L. Nustin and P'. $\Lambda$. House. 
Because the potential value of the resource, other than the methane, is now generally expected to be a small part of the total, in this study we assume that the competitiveness of the geopressured resource is determined principally by the cost of producing the methane, adjusted by appropriate credits for the other "by-products." This approach reverses the historical one in which the geopressurcd zones were thought of principally as a geothermal source for the production of electricity, and that any gas which might be extracted would be the by-product whose sale would reduce the cost of the power. This change in the historical perspective has been cncouraged by the current belief that the amount of gas produced might be much greater than had been previously anticipated, and because the price of natural gas increased so rapidiy during the 1970 s. 
II . THE ENERGY POTENTIAL OF TIE GULF COAST GEOPRESSURED ZONES

\section{A. The Resource Base}

The cnergy resource base of the ciciz includes mechanical energy, heat cnergy and natural gas." of these the natural gas may not be the largest in terms of B'lu content, but cven without any free gas very probably contains most (over 2/3) of the economic potential. ${ }^{*}$ Consequently it will be convenient in this analysis for us to focus upon the potential value of the gas, keeping in mind, however, that over time the full value of the resource could be increased by as much as 50 percent as we learn how to commercialize the available heat and mechanical energy (sec scction III). The value of the methane at the wellhead will be taken to be equal to the cost of some competing fuels (c.g. decp gas or LNG), which today would probably cost at 1 cast $\$ 3$ per MCF in 1978 dollars. That is, $\$ 3$ billion for each TCF (or for each quad, since these two units are nearly equal).

The carly flurry of cxcitement that began in 1975 over the GCGZ potential appears to have stemmed from the 24,000 quad estimate by the USGS, mentioned earlier. Even their extended estimate that the GCGZ might contain as much as 84,000 quads in methane alone was criticized as too conservative by geology professor Paul $\mathrm{H}$. Jones, who provided an estimate of over 100,000 quads of methane.* Either of these numbers is so enormous that it naturally induces thoughts of a potential natural gas energy "panacea." There have been and will be other more conservative projections by numerous "experts" associated with geopressured projects (see table 1). The quotes around the term experts are used to remind readers that the entire subject is so embryonic that no projections can now be accepted as much more than a preferred scenario. It will take many years before reality experiences will be able to place reasonable bounds upon such scenarios; until then, planners will have to cope with the very large range of possible outcomes which "experts" produce.

This estimate is based upon the relative amount of electric power which can be produced from each energy source. It assumes the brines are saturated with methane. See: W. M. Brown, 100,000 Quads of Natural Gas?

*p. II. Jones in Unconventional Sources of Natural Gas, Nationai Academy of Seicnees, 1976. 
Table 1

SOMI: IESTIMATI:S OI THI: MFTHIANE RI:SOURCI: BASI: IN THE GCGZ

\begin{tabular}{|c|c|c|}
\hline WILLIAM UISI: (LSU) & & 3,000 \\
\hline MYRON DORFMAN (UNIV. 0 & OF TEXAS) & 5,735 \\
\hline USGS (PAPADAPOULOUS, E & ET AL.) & $23,618-84,000$ \\
\hline PAUL JONES & . & $49,000-100,000$ \\
\hline
\end{tabular}

The resource base estimates generally assume that the brines in the GCGZ are saturated with methane. Concern about the accuracy of this assumption was expressed by most of the investigators but until late in 1977 their principal concern was that some geopressured reservoirs might be substantially less than saturated. Perhaps because the resource-base numbers were already so large as to be mind-boggling almost no mention was made of the opposite possibility--that the brines might be supersaturated in methane. That is, could not some free gas also be dispersed in the sandstone reservoirs in amounts which might significantly increase the production estimates? The possibility of substantial amounts of free gas in addition to dissolved gas burst forcefully into the scene when DOE-sponsored tests on the reopened Edna Del Cambre \#1 well in Louisiana produced much more gas than could be accounted for by methane-saturated waters.* Since this test yielded the first hard production data it naturally led many analysts to conjecture that free gas in the GCGz might be the rule not the exception. If so, any previously published resource estimates should all be increased. Moreover from these results an early, and admittedly rough, analysis of GCGZ production potential suggested that over time the amount of gas that could be extracted per barrel of fluid might be 2.5 to 6 times greater than that previously estimated.** If this possibility is subsequently confirmed then a11 the prior economic calculations would be grossly in error. The added prospect of the free gas has created some unusual excitement about commercial potential of the GCGZ because any added gas should become available with only trivial increases in capital or production costs.

*Papers by Bill Osborn and Denton Wieland, in Proceedings from the Third Cicopressured Geothermal linergy Conlerence, edited by John Neriwether, November 16-18, 1977 .

** Ibid., paper by lor. Whilip Randolph. 
On the other hand it has been asserted that the frec gas potential is probably a myth. For cxample Charles Mathews, a petrolcum enginecr with Shell oil, has stated that the socalled free gas in the Edna De La Cambre well was actually a small gas accumulation that was predictable rrom a careful cxamination of existing welt logs, and should not be considcred at all typical. Indecd, Mathews claims that gas migration theory precludes the possibility of frec gas except where it might accumulate in gas caps, because free methane gas otherwise would slowly diffusc upward and would escape from the geopressured reservoir.* Mathew's conclusion is likely to be proven or disproven very soon by the data expected from the Brazoria well.

\section{B. The Zones Between 20,000 and 30,000 Feet}

The resource base which might exist from 20,000 to 30,000 feet was estimated by the USGS (Circular \#726) and by Professor Jones. ${ }^{*}$ These courageous estimates are inherently very uncertain since the geological data upon which they were based was quite meager. However, what is not contested about these zones is that geopressured water will be present, that the temperature will generally increase with depth, and that with higher temperature and pressure the amount of methane dissolved in saturated waters increases substantially. Data showing how fast methane solubility in pure water increases with higher temperatures and pressures has been established in laboratory tests (figure 2). However the complete set of experiments which must be done to cstablish this solubility precisely in the presence of dissolved salt is yet to be completed. Nevertheless there is little disagreement about the approximate expectation. Jones estimates that in going from 18,000 to 25,000 fect in depth, and assuming a temperature increase from 400 to 500 degrees Fahrenheit that the solubility of methane should just about double.** Although the sand beds at such depths are still expected to have substantial porosities, the permeability of these beds are expected to decrease with depth--perhaps sharply.**** However it has

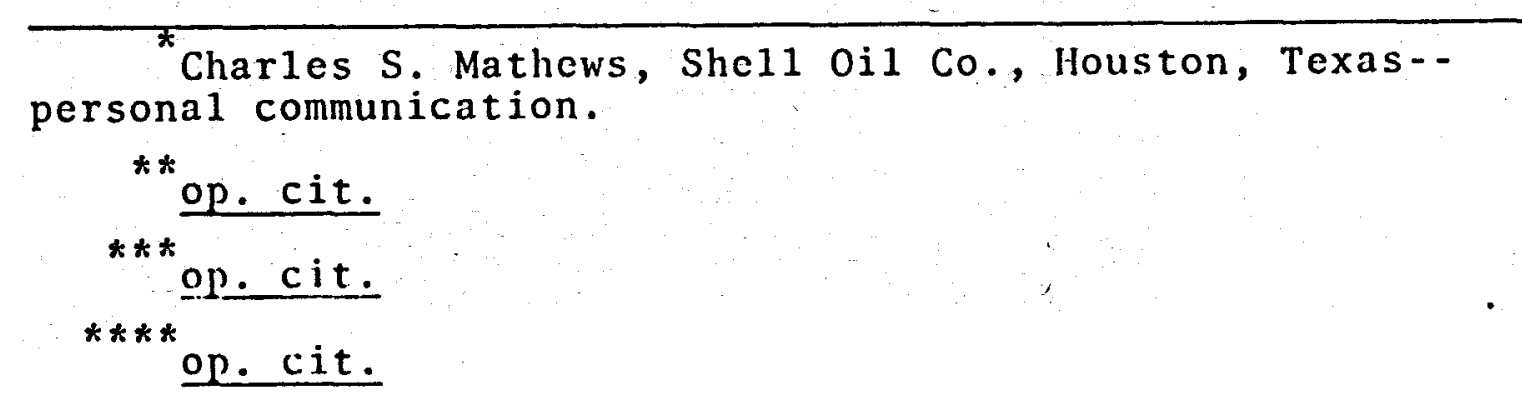




\section{Figure 2}

SOLUBILITY OF METHANE IN FRESH WATER

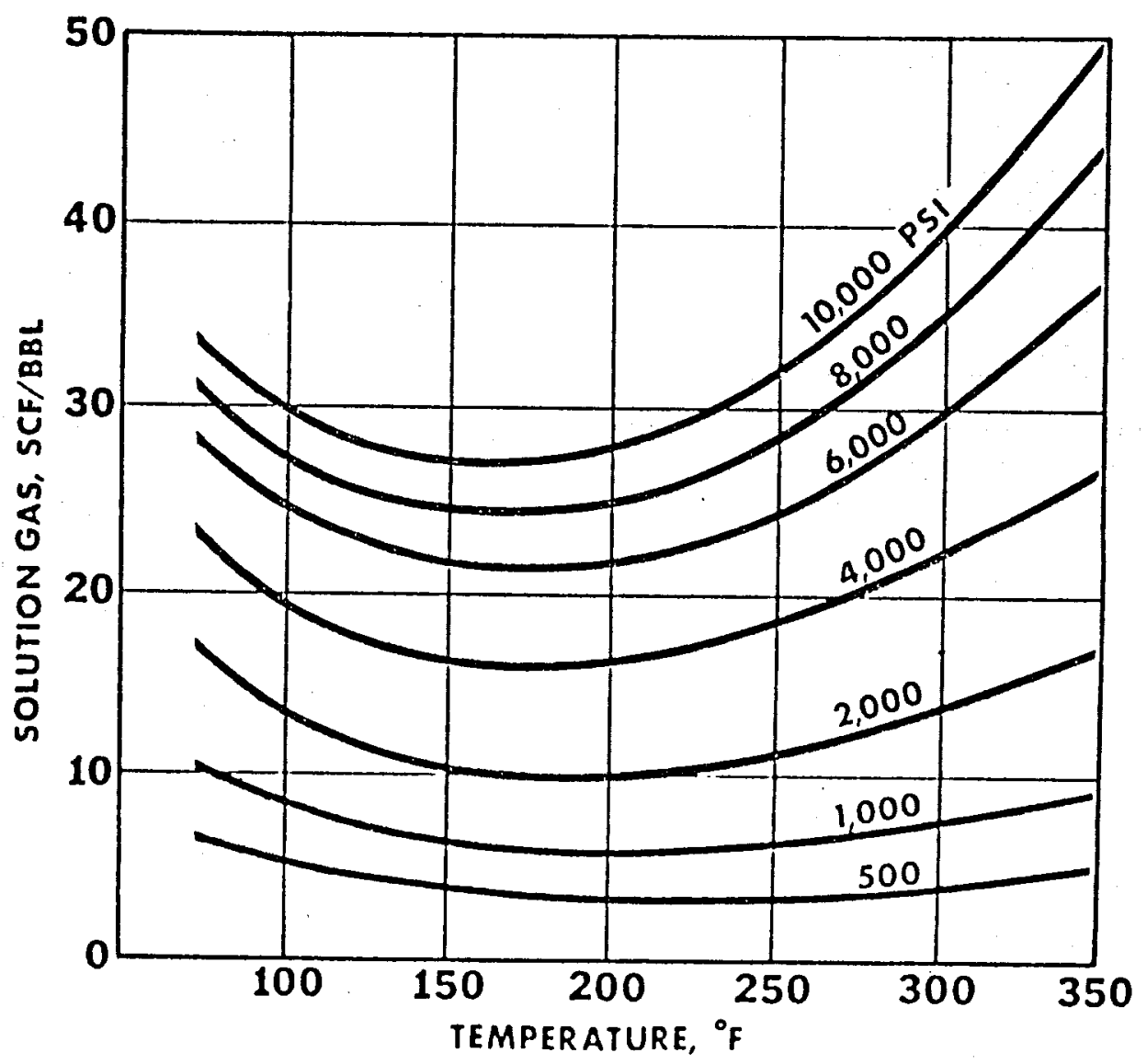

SOURCE: PROCEEDINGS FROM THE FIRST GEOPRESSURED GEOTHERMAL ENERGY CONFERENCE, EDITED BY MYRON H. DORFMAN AND RICHARD W. DELLER, JUNE 2-4, 1975, P. 79. 
been claimed the loss of permeability might be at least partially offset by the use of massive hydraulic fracturing (MHF) together with high-strength propping agents to kecp the induced rractures from resealing. Consequently while we must anticipate greater technological dilliculties in going to greater depths, hopefully the added costs can be sufficiently compensated for by producing fluids which have a much higher gas content--as we 11 as heat content and mechanical energy.

Morcover, at sufficiently great depths we may also need to take into account the solubility of oil in these brines. Although dissolved oil is a conjectural source of energy, some of the theory (backed by some experiments) which indicates the potential for both oil and gas to be dissolved in the waters of these deeper zones has been presented formally by Dr. Leigh Price of the USGS. * Price concludes that at sufficient depth (and when temperatures excecd $200^{\circ} \mathrm{C}$ ) that the solubility of both methane and crude oil tends to increase exponentially with depth, and therefore that zones between 20,000 and 30,000 feet might contain a major portion of the hydrocarbons which could be produced (see figures 3 \& 4 ). price also claims that the presence of either dissolved or free methane would increase the potential associated quantities of crude oil by incrcasing its solubility in the geopressured fluid. Furthermore, he asserts that sufficient evidence exists to at least cast doubt upon the simple expectation that porosities and permeabilities in these formations need necessarily decrease rapidly with depth, in accordance with experiences in "standard" oil and gas reservoirs. Should Price prove to be correct, at least in some of the deep geopressured reservoirs, then the potential hydrocarbon production could be much greater than is now expected. Although Price's evidence introduces the possibility of a huge additional potential for production of natural gas--and possibly some crude oil which might also be dissolved in these deep waters--his views are quite unorthodox and hard evidence from field tests will be required before any of them are likely to become accepted.

\section{Zones Be1ow 30,000 Feet}

30,000 feet is near the limit of current drilling experience and, therefore, 1 ittle solid information exists about the nature of the Guif Coast formations at such depths. Moreover, much of the information that might otherwise be available

\footnotetext{
"rocedings from the Third Geopressured ficothermal lincrgy Conterence, edited by John Neriwether, Noventer $16-18$, 1977 .
} 


\section{Figure 3}

PRODUCTION POTENTIAL OF SATURATED BRINES

THOUSANDS OF CUBIC FEET(MCF) OF GAS PRODUCED PER YEAR

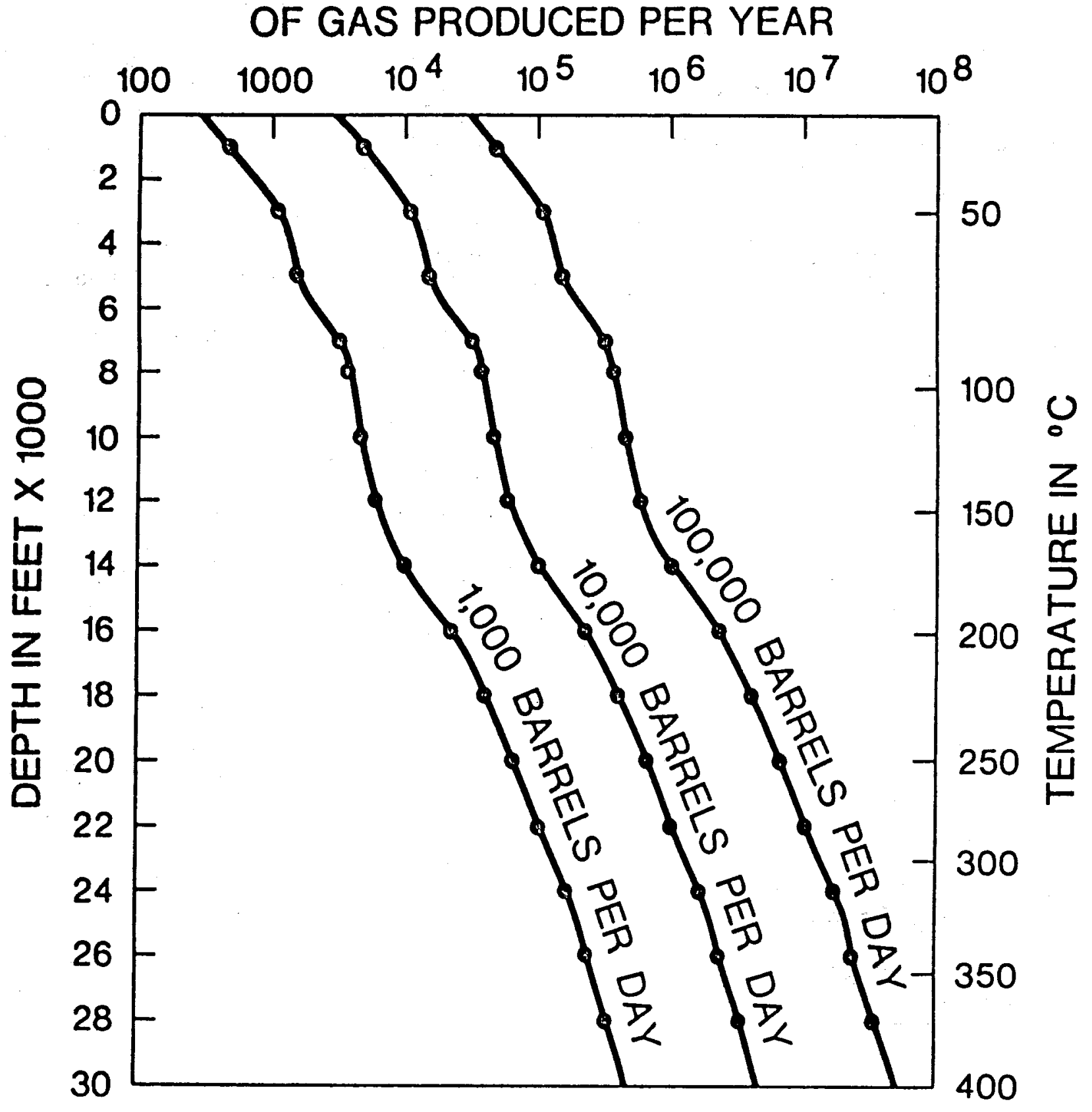

SOURCE: LEIGH PRICE, IN PROCEEDINGS FROM THE THIRD GEOPRESSURED GEOTHERMAL ENERGY CONFERENCE, EDITED BY JOHN MERIWETHER, NOVEMBER 16-18, 1977, P. GI-247. 
Figure 4

HYPOTHETICAL CRUDE OIL PRODUCTION POTENTIAL-FROM SATURATED BRINES

BARRELS OF CRUDE OIL PRODUCED PER YEAR

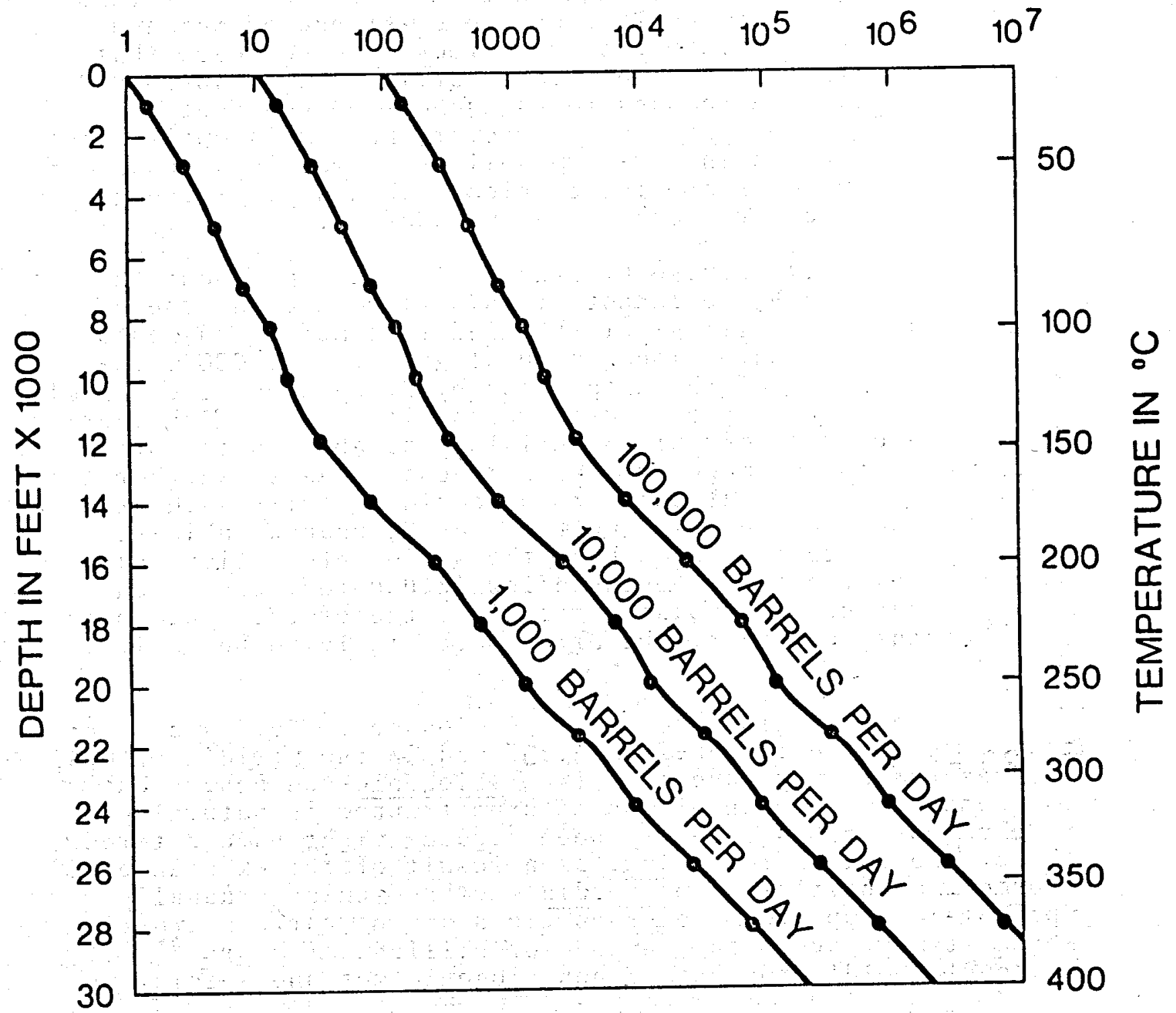

SOURCE: LEIGH PRICE, IN PROCEEDINGS FROM THE THIRD GEOPRESSURED GEOTHERMAL
ENERGY CONFERENCE, EDITED BY JOHN MERIWETHER, NOVEMBER 16-18, 1977 , P. GI-248. 
is of a proprictary nature. However, in the U.S. there is a growing interest in the potential for obtaining natural gas from drilling into decper zoncs. This interest was expressed recently by Robert $A$. Hefner of the Gllk Corporation and chairman of the American Gas Association's Independent Gas producers Committee. Ilefner's company has drilled the very decpest well in the U.S. $(31,441$ fect $)$. As a result of his findings he has claimed that this "allows us at this point to project with confidence the existence of methane down to depths of 60,000 fect." Moreover he believes that drilling contractors may be able to drill between 40-50,000 feet currently, and perhaps to as much as 60,000 feet in the "next couple of years."* Moreover, llefner is optimistic that for deep wells in low-permeability formations the use of massive hydraulic fracturing coupled with new high-strength agents might graitly increase gas production.

Since we will devise hypothetical scenarios about the geopressured zones, we cannot at this time rule out the extension of deep drilling--of the kind that Hefner suggests is possible for conventional natural gas--to the GCGZ, especially in light of the data shown by price about the rapidly increasing solubility of hydrocarbons with depth. Considering only the amount of organic materials available in the original sediments one might raise the question as to whether the geopressured waters at such depths could be fully saturated with methane. While this question may be unanswerable--except by field tests--we do have the solid information that many gas reservoirs at depths below 22,000 feet have been found along the Gulf Coast suggesting, therefore, that up to those depths, at least, the brines are likely to be fully saturated.

Interest is also growing in Professor T. Gold's concept that much of the methane that is found in the world's natural gas reservoirs may have come from abiogenic sources. That is, some or even much of the methane trapped in natural gas reservoirs--it has recently been argued--might have entered these reservoirs from below, as a result of the existence of enormous quantities of primordial methane which gradually "percolates" up from deeper portions of the earth's crust where it may have been trapped for billions of years.** If we couple Gold's concept of non-biogenic methane seeping up

\footnotetext{
*hemical Weck, July 12,1978 .

**

Thomas Gold, ferrestial somress of carbon and liarthquake Outgassing, Corncil Mniversity, November 1978 (to he published in Journal of lectrol cum (ieology).
} 
into reservoirs from below with our knowledge of the solubility of methane, then we can be somewhat morc optimistic about the possibility that the waters in these decper geopressured zones would be saturated--and possibly even supersaturated. Thus, to carry an optimistic scenario to its most hopeful conclusion, waters supersaturated in methane may exist throughout most of the geopressured regions of the Gulf Coast, down to whatever depth we might be able to drill in the future.

If we extend Price's solubility chart (figure 3) down to depths much below 30,000 feet and temperatures in excess of $400^{\circ}$ [ then, if this extrapolation is valid, we begin to approach the point where the amount of methane dissolved in the brine, potentially, may cxceed the amount of water present. Within such regions--that is, where the amount of methane is comparable to or greater than the amount of water in the formations--a somewhat less difficult problem in producing this fluid should be expected. In the petroleum industry it is well known that as the fraction of water in a reservoir is reduced that the ability of the natural gas to move through the formation increases quite rapidly. In addition viscosities diminish at the higher temperatures.

In this section we are offering a deliberately optimistic interpretation of the possible production of gas from these very deep zones. The "normal" expectation is that not only would the drilling be difficult but that the production of gas from the brines is unlikely to be commercially interesting. However these interpretations are not made from data or direct experience but rather from intuition based on past experiences with "analogous formations." Because we have no solid evidence with which to contest such judgments we base optimistic scenarios upon the vast uncertainties which necessarily exist when intuition is applied to geological realms which are considerably different in character from those of normal expericnce. Morcover, advancing technology over time tends to support optimistic views. With respect to potential production from the GCGZ a significant amount of practical experience from which to make extrapolations is clearly lacking. Consequently, professionals fall back upon hypotheses and intuition. This explains, in part, why the range of "expert" opinions about the geopressured potential varies over such great extremes.

To recapitulate, the most optimistic picture for the deeper zones visualizes the possibility, if all the cards fall into place, that with greater depth not only do the increasing pressures and temperatures imply increasing amounts of dissolved methane, but (a) porosities and permeabilitics 
will be found to diminish less rapidly with depth than what one would expect from normal experience in other natural gas reservoirs, (b) an added potential for significant amounts of free gas--which might even be relatively greater with depth, and (c) an increasing possibility for recovering dissolved oil-like hydrocarbons as well as methane. If such reservoirs do in fact cxist and are commercial--or can become so within a few decades--then it might become possible to tap into a new source of natural gas, and possibly other hydrocarbons, so enormous as to completely dwarf all current conventional expectations.

On the other hand, it may be found that an effective cutoff to the production of gcopressured fluids exists at some depth--perhaps well above the 30,000 foot level. Or, if the optimistic scenario partially prevails, it may be that a practical cutoff would exist, but only at 35,000-40,000 feet, and that above this level a number of commercial reservoirs could be produced. Those interested in this potential might find some excitement during the next decade or two. 
III. THE GLOPRESSURTE GEOTHERMAL RESOURCI, WORLDWIDE

As pointed out by Professor Pau1 H. Jones, "All Cenozoic " oil-producing sedimentary basins are geopressured at depth..." (Geopressurc refers simply to fluid pressures greater than hydrostatic, which for water is generally taken to be a pressure of .433 psi per foot of depth--but which is larger in a salt water environment, such as that of the Gulf Coast where it is normally .465 $\mathrm{psi}$ per foot.) Gcopressure is frequently experienced during drilling, especially when drilling in relatively deep formations. Fluids at greater than hydrostatic pressure must be well sealed within their reservoirs, else enough would soon leak out to bring the reservoirs to normal hydrostatic pressurc. The most common geopressured fluid is brine, but the ones generally sought are pctroleum and natural gas. Often, all three coexist in the same reservoir.

Although it has long been known that the geopressured brines which are known to underlie the Gulf Coast contain dissolved natural gas--or methane, the principal component of natural gas--it has on 1 recently been appreciated that they are likely to be saturated (perhaps even supersaturated) with methane, and that separating the dissolved methane from the produced fluid might become a commercial process at competitive prices. The fact that the fluids in the GCGZ tend to be moderately hot has two important consequences: (1) at high pressure and above $90^{\circ} \mathrm{C}$ methane solubility increases with temperature; and (2) the highly-pressured hot brine may have several practical uses as an energy source.

The concept of deliberately seeking to find and produce the hot water from the reservoirs of the Gulf Coast for commercial purposes is relatively recent, and one which may or may not prove to be practical in the twentieth century. If it does become a commercial success, however, these energy reserves might then become enormous. Consequently, another question arises at once: Are the Gulf Coast formations unique, or are they mercly the first manifestation of a widely-occur$r$ ing phenomenon around the world? Because almost no authoritative specific ficld information cxists which can provide an acceptable answer to this question we can only speculate about it at present. In principle, such speculation could be based upon existing published data which allows a comparison

* $p$. H. Jones, Gas in Geopressured Zones, in The Future Supply of Nature-made Petroleum and lias, R. li. Meyer, lid., Pergamon Press, 1977 , p. 889. 
of the physical properties of various sedimentary basins, that in turn would determine where similar productive geopressured reservoirs might be located.

Unfortunately, such comparisons cannot be trusted if the evidence is based only upon accurate pressure and temperature data in geopressured zones. Since much of such cxisting data is still proprietary, and its accuracy is not always reliable, any general conclusions about "similar" zones must be quite speculative.

In his book, Abnormal Formation Pressures, Walter Fertl presents and discusscs some of the available data, and indicates the general locations of geopressured areas in many regions of the world. For example:

Overpressures also occur in several Canadian areas. These include the Rainbow Lake area in western Canada, off the West Coast, off the East Coast, under the Nova Scotian Shelf, and in the MacKenzie Delta area both on- and off-shore.*

Fertl offers evidence for the existence of geopressured formations in all continents and presents some of the available data associated with selected areas in Europe, North America, the Soviet Union, South America, the Indian Subcontinent, the Far East, and the Middle East. Some of the European data is indicated in figure 5 (Fertl, p. 326). However, he does not attempt to answer the question asked above. It is difficult, however, to avoid the impression that geopressured formations are almost ubiquitous and that they may, in a crude sense, be "randomly" scattered over the sedimentary basins of the world.

Professor Jones, in a presentation to an international petroleum conference in 1976 stated his general qualified conclusion that:

The natural gas resources in geopressured zones worldwide are very great indeed if conditions in them are comparable to those in the Northern Gulf of Mexico basins.**

Walter 11. Fertl, Abnormal Formation Pressures, Elsevier Scientific Publishing Company, 1976, p. 336.

** P. Il. Jones, (ias in Geopressured Zones, in the liuture Supply of Nature-made letrolcuin i lias. 


\section{Figure 5}

\section{SELECTED ABNORMAL FORMATION PRESSURE DATA, ON- AND OFFSHORE EUROPE}

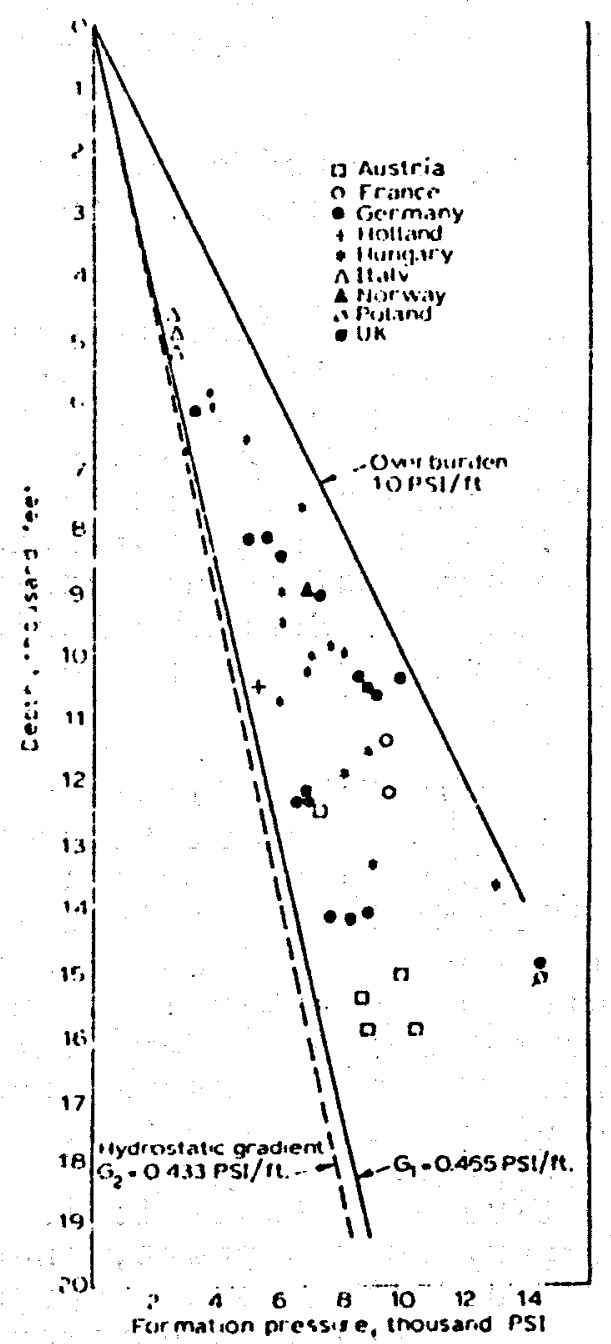

SOURCE: WALTER H. FERTL, ABNORMAL FORMATIIII PRESSURES, ELSEVIER SCIENTIFIC PUBLISHING COMPANY, 1976,

P. 326. 
He then mentions some of the less well-known technical factors which affect the development and characteristics of these zones over time: the fluid release mechanisms, hyperfiltration, osmotic forces, elastic moduli, structural deformations, heat flow, and viscosity. The large number of influential physical factors coupled with the sparsity of specific data suggest that it is very risky--if not foolish--to assert any comparability of potentially commercial resources in different locations.

Jones divides the geopressured occurences into two types: depositional and tectonic. In reference to North America he states that:

...geopressured zones of the depositional type are found in a belt almost circling the Gulf Basin from southern Mexico to Western Florida; in the Anadarko Basin of Oklhoma; in the Permian Basin in West Texas; in several Rocky Mountain basins (Colorado, New Mexico); in the Williston Basin (North and South Dakota); perhaps in some California basins; in the Alaska North Slope and the Sverdrup Basin of the Arctic Occan Margin; and in some places in the Western Canada Basin.*

It is clear from the available literature that the present state of knowledge is insufficient to compare the resources within the geopressured zones along the coasts of Texas and Louisiana with those which might exist in the rest of the world. From purcly area considerations, however, the GCGZ would seem to constitute considerably less than 10 percent of the world's geopressured basins. For want of any authoritative estimates we have chosen to assume that the energy resources within the GCGZ are 10 percent of those of the similar resources in the geopressured zones of the rest of the world. While on a relative area basis it is a conservative estimate, that alone is very poor support, indeed, for any claim to reliability. Thus, the above 10 percent figure should only be regarded as a gross assumption made for want of a better approach, and one which contains almost none of the hard supporting data that entrepreneurs would require to start drilling. Nevertheless, it will be useful for our subsequent discussion since few conclusions would be altered if the assumption were in error by even a factor of five, on either the high or low side.

"P. Il. Joncs, Gas in Geopressured Zones, in The liuture Supply of Nature-made Petrolcum if Gas. 


\section{DFMAND PROJECTIONS FOR OIL AND GAS}

The inherent uncertainty in making long-range projections for oil and gas may be visualized as lying in the possible variation of threc principal factors: (1) the average cconomic growth rate between now and a selected time in the Tuture; (2) the allount of energy which will then be required per unit of GNP, or GIVl, and which may be expresscd in terms of a relative conservation factor (a conservation factor of .5 means that at that point in time it will take 5 times as much energy per unit of GNP than it did in 1977); and (3) the fraction of the primary energy supplies which will then be supplied by oil and gas. Although we can be reasonably accurate in projecting each of the above three factors only a few years into the future, for projections over several decades the uncertainty can become quite large. It would be foolish to claim more than a rclatively poor idea as to what the world's average cconomic growth rate will be over a period of 20 to 70 years even though economists projections tend to vary surprisingly little. What the applicable conservation factor might be, or what overall impact government regulations, luck, now technologics, cartcls, ctc., will have on the relative fraction of energy to be supplied by oil and gas during the next century is also necessarily quite uncertain but we have made simple estimates of these two parameters based on projections of many recognized authorities; these are shown in figure 6 .

Using these estimates the future situation can be portrayed rather simply by plotting the energy requirements, or the oil and gas requirements, as a function of average economic growth rate. This has been done in figure 7 , which indicates both the projected total energy requirements and the oil and gas requirements for the U.S., as well as for the world as a whole. The average economic growth rate in this figure is assumed to 1 ic somewhere between 1.5 and 4.5 percent. These arbitrary limits can, if desired, be cxtended casily since the plots are lincar. Thus figure 7 displays the U.S. GNP and world's GWP in the year 2000 , and in the year 2050 , relative to that in 1977 . Thesc estimates as well as the relative energy consumption, are represented by straight lines when plotted on semi-log paper.

Based upon the projections in rigure 6 , we can reasonably assume that the conservation factor for the U.S. is equal to

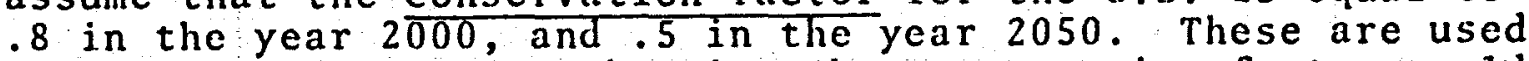
in plotting figure 7: Changing the conservation factor would move the entire projection of energy demand in figure 7 vertically by an amount proportional to that change. We belicve 
Figure 6
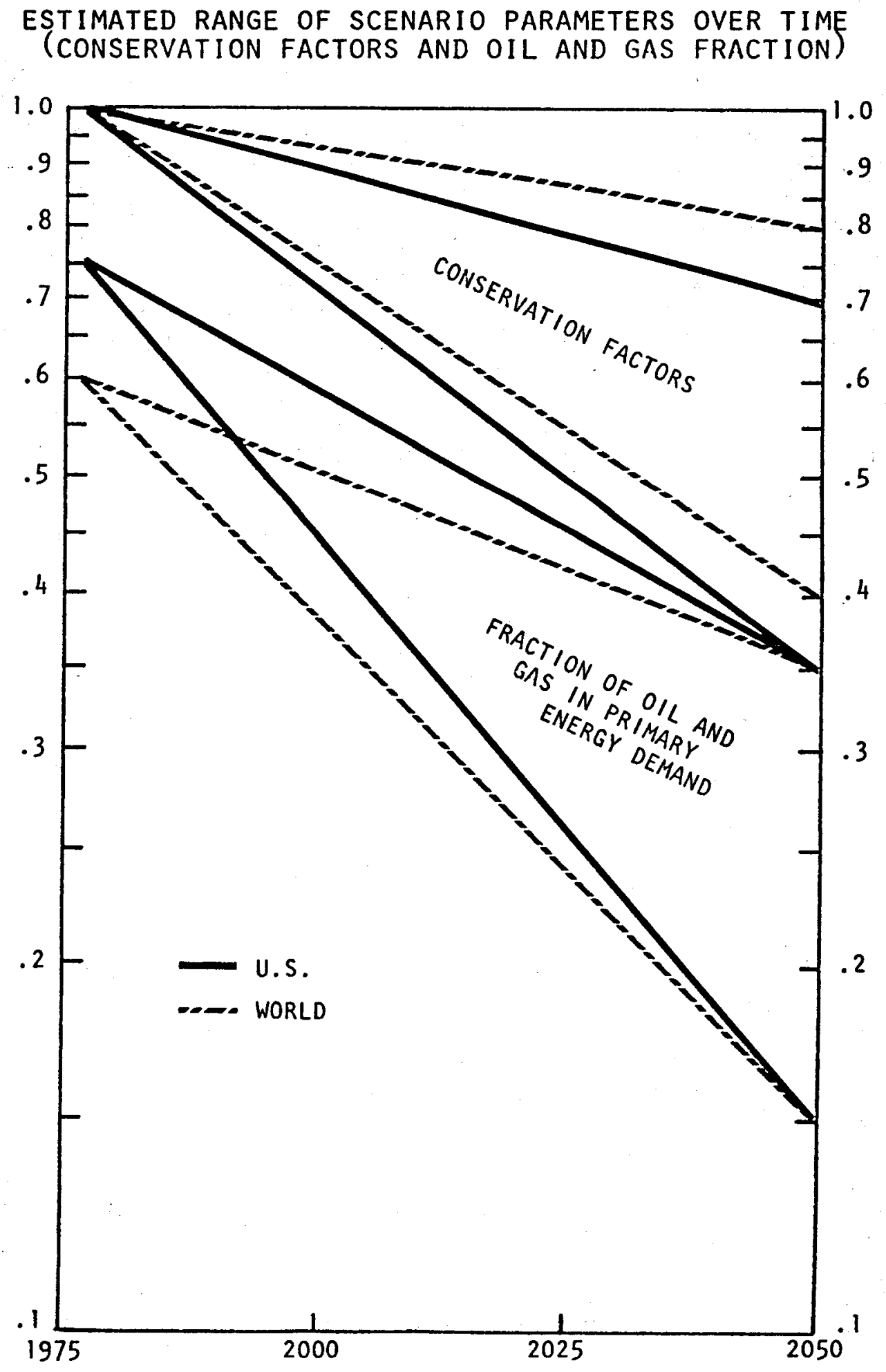


\section{Figure 7}

\section{PROJECTIONS OF ENERGY DEMAND RELATIVE \\ TO AVERAGE ECONOMIC GROWTH RATES \\ FOR U,S, AND WORLD IN YEARS}

2000 AND 2050

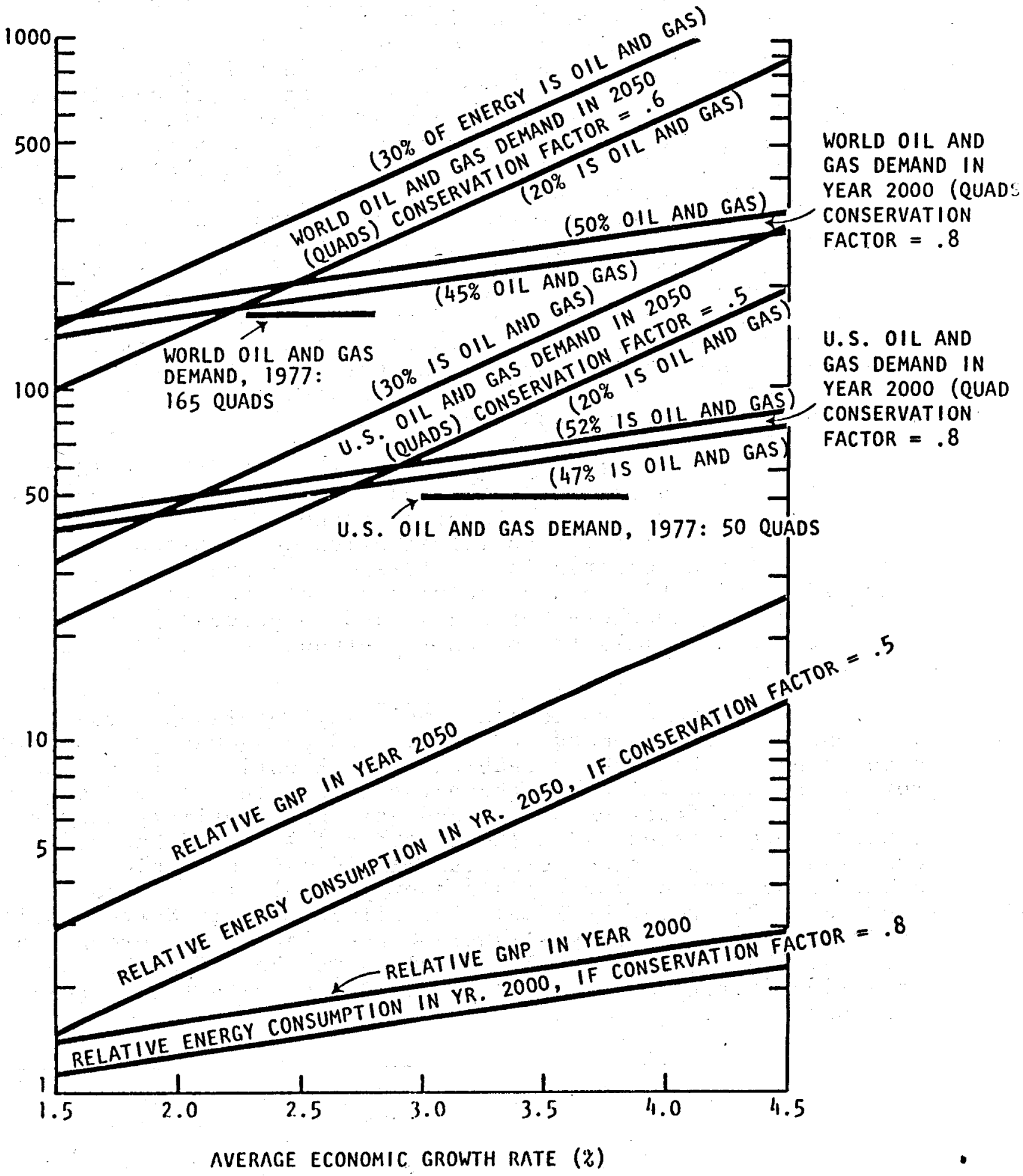


that the chosen value for this parameter in the year 2000 (.8) is quite reasonable, in the sense that most analysts would probably place it somewhere between .7 and .9 . The uncertainty in this factor for the year 2050 is greater, as figure 6 shows; in our judgment most "experts" would probably place it somewhere between .35 and .75 , the specific choice depending upon the optimism or pessimism of the "experts"; we use. 5 for the calculations in that year.

As indicated in the upper part of figure 7 , U.S. demand for oil and gas in the year 2000 should not significantly exceed present demand, unless the average growth rate of its economy during the rest of the century is well in excess of 3.5 percent, assuming that our choice of a conservation factor, .8 , and of the fraction of energy consumption to be met then by oil and gas, 50 percent, (it was 75 percent in 1977) are both acceptable. For the year 2050 we observe that unless the average economic growth rate over the 73-year period exceeds 3 percent the U.S. demand for oil and gas would not increase by more than a factor of two--and it might not increase at all--if our estimate is correct that the fraction of energy to be supplicd by oil and gas in that year is between 20 and 30 percent, and if the assumed conservation factor of .5 is a reasonable one.

A similar projection shown in figure 7 for the world's demand for oil and gas indicates that it is apt to exceed. the present requirements for average economic growth rates of 2.2 percent or more. The illustration we have chosen assumes that the conscrvation factors are .8 and .6 in the years 2000 and 2050 , respectively, and that the fraction of oil and gas is somewhere between 45 and 50 percent in the year 2000, and shrinks to somewhere between 20 and 30 percent in 2050 .

While figure 7 provides a simple way to present projections of cnergy demand and of oil and gas demand, it should also be useful because it enables a quick estimate to be made for any selected values of the parameters. In figure 7 our values for the fraction of oil and gas in the primary energy supply are çonsistent with those of the 1977 World Energy Conference. That study expects oil and gas to furnish about 46 percent of the world's energy supply in the year 2000 , and 28 percent by 2020 . For oil and gas in North America their estimates are only slightly higher, about 50 percent for the year 2000. In figure 7 the values we chose for the conservation factors are reasonably consistent with their projections.

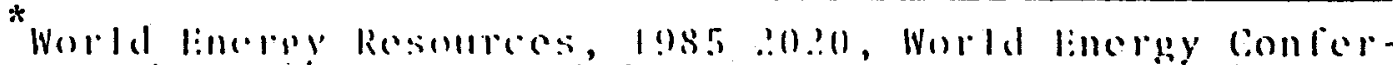
cnce, lic sidence and rechnologyy leess, surrey, lingland. 
A. The Basic Scenario

For what they are worth, most projections of future cconomic growth over the rest of this century tend to rall within a 2.5-4.0 pereent range for the U.S. and a 3.0-4.5 percent range for the world. Beyond 2000 the estimated growth rates tend to drop .5-1.0 percent per quarter century. For our Basic Scenario we will assume that the above ranges provide reasonable bounds for average economic growth rates to the year 2000. For the average growth rate to the year 2050 we lower the ranges by $3 / 4$ of a percentage point. Thus the assumed economic growth rates for the U.S. and the world in our Basic Scenario are given below:

\section{AVERAGE ECONOMIC GROWTH'RATES}

\begin{tabular}{|c|c|c|}
\hline & $1977-2000$ & $1977-2050$ \\
\hline ORLD & $\begin{array}{l}2.5-4.0 \% \\
3.0-4.5 \%\end{array}$ & $\begin{array}{l}1.75-3.25 \% \\
2.25-3.75 \%\end{array}$ \\
\hline
\end{tabular}

These ranges plus the choices for the conservation factors and the fraction of oil and gas complete the parametric values needed for the scenario.

With these choices we find from figure 7 the following range for oil and gas demand (in quads):

OIL AND GAS DEMAND--BASIC SCENARIO

$\begin{array}{lrrr} & \frac{1977}{4} & \frac{2000}{2050} & \frac{2050}{40} \\ \text { U.S. } & 50 & 50-66 & 26-115 \\ \text { WORLI } & 165 & 195-310 & 170-720\end{array}$

In this scenario we observe that in the year $-2000 \mathrm{U} . \mathrm{S}$. consumption of oil and gas will be about the same as or a little greater than current consumption, but that in 2050 it can vary anywhere from about half to over twice current consumption. For the world as a whole oil and gas consumption is seen to increase between 18 and 88 percent by year-2000; by 2050 , however, the change in demand can range from a small ( 3 percent) increase, to more than a quadrupling. 
We assume that the demand for oil and gas portrayed above reasonably brackets future reality and proceed to inquire where these fuels will come from. The many possibilitics include a continuation of conventional discoveries, synthetic fucls from coal and shale, and unconventional sources of these hydrocirbons--one of which is the methane from the geopressured zones of the (iulf Coast. lo meet the upper end of the demand range, at least a few of these possibilities, if not most, may need to become commercial realities.

In this study oil and gas are lumped together as if they are readily substitutable. This is true in large measure today, because oil or gas used as industrial fuels generally can easily be switched. Although liquid fuels are usually required for automotive and most other transport vehicles, only about one-half of present oil consumption in the world is used in transportiaion. Thus there is much room today to use more gas and less oil, or vice versa. We are assuming that this will also be true during the next 75 years. To some extent this flexibility will be aided by future production of synthetic fucls from coal shale, peat, wood and/or waste organic materials, some of which appear almost certain to enter the $21 \mathrm{st}$ century commercial market on a large scale. In most of these options the process can be designed to emphasize the production of either gaseous or 1 iquid hydrocarbons. Thus the possible switching of gas and oil may become applicable to some producers as well as consumers. This potential further supports the assumption that the demand for oil and gas can be combined in analyzing future energy problems.

We have taken the trouble to discuss the substitutability of oil and gas principally because of the possibility that sometime after the year 2000 gas, rather than oil, would be come the dominant commercial fuel. If that happens, then the use of liquids as boiler fuels, and in some cases as transportation fuels, will tend to be phased out where gas is available. Moreover, gas can be converted to liquid fuels, if necessary, even though the reverse process--liquids into gases--is today's commercial reality for the most part. We now are ready to examine the potential contribution of geopressured methane to the demand for fluid fuels. 


\section{THE POTENTIAL ROLE OF GEOPRESSURED FNERGY}

\section{^. Economics of (icopressured Production}

The feasibility of producing energy from the GCGZ appears likely to depend upon the commercial feasibility of producing the dissolved methanc. That is, if it can be shown that reservoirs exist from which the methane might be commercially extracted, then the other potential uscs of the geopressured brines (such as for hot water, electricity, minerals, or mechanical energy) could only improve the economics somewhat. The feasibility of commercial production evidently is going to depend upon a number of factors which are very uncertain at present. These factors include reservoir size, the volume of recoverable gas per barrel of fluid produced, the cost of reinjection (or other means of disposing of the spent brines), as well as the costs of the production wells (including capital, operating and other costs such as royalties and taxes).

Even now among analysts there are relative optimists and relative pessimists who have their preferred ways of making these calculations. One relatively optimistic set of calculations is found in a paper by Dr. Philip Randolph**, while another more pessimistic set was recently given by Todd Doscher and others.** Not unreasonably the results in each of these papers tend to reflect a number of judgments by the writers. The range of outcomes is so great that Randolph's production costs vary from less than $\$ 1 / M C F$, to more than $\$ 10 / M C F$ while Doscher's range from about $\$ 2.50 / \mathrm{MCF}$ to $\$ 16 / \mathrm{MCF}$. Although it is always possible to calculate some minimum and maximum production costs for "reasonable" reservoirs it is unlikely that any such theoretical calculations would become persuasive to investors--at least not in the very near future. Practical investment judgments, we expect, will depend much more upon the reality experiences associated with field testing. Such testing has only just begun and during the coming months (and years), analysts will be pouring over the hard data as it is gathered in order to narrow the present range of estimated production costs.

\footnotetext{
* Section III has a more elaborate discussion of this point.

** Philip L. Randolph, Natural Gas From Gcopressured Aquifers, Socicty of Petrolcum Engincers, SPE 6826, 1977.

***

Todd M. Doscher, et. a1., The Fconomics of Producing Methane from the cicopressured nquilers of the ciul coast, University of solltiern bitfornia, lept. of petroleum linginccring, March 30,1979 .
} 
In this paper we will assume a spectrum of potential economic reserves, over time and use these as a basis for production scenarios from which we can draw implications for the future of the GCGZ. For this purpose it is necessary deliberately to discard the more pessimistic analyses which suggest that the cost of producing methane from these zones might be greater than $\$ 5 / \mathrm{MCl}$, since at that price we believe that competition from alternate energy sources would effectively preclude commercialization. After the results arrive from a number of field tests, while it might be found that the production of energy from the GCGZ will not be commercial, we now need to assume that that outcome is not an interesting case. Thus, we focus on scenarios which are all somewhat on the optimistic side.

For any scenario we could assign probability distributions around the assumed average production costs--and examine them for their interesting implications. However, as in normal exploration, the cost of production from any single reservoir or well is affected by luck. Only after many wells have been drilled can reasonable expectations be determined, and therefore the potential competiveness of a particular operation. In our success scenarios energy prices are determined by the market; in turn, the extent of any commercial reserves over time would be sensitive to these prices. This kind of detail, however, is important from an operator's point of view, but not from a national or global one spanning several decades. These later perspectives are concerned with the amount of regional production which can be developed at expected prices--ones which are at least marginally competitive with alternative energy sources. In none of our scenarios do we assume that GCGZ production becomes cheap. Rather we will assume that it is merely commercial at some production rate which is scenario dependent. Whether or not production is subsidized during the early years (1985-2000) is also scenario dependent but relatively insignificant in cost, because large-scale production is not expected much before the turn of the century, if then, even with very optimistic outcomes.

\section{B. Alternative Sources of Gas}

After the year 2000 we expect that economics and politics will continue to influence production of natural gas everywherc, and from the GCGZ, in particular. Production economics will be affected by many factors whose impact is necessarily uncertain at present. For cxample, the prices of imported fucls might for a time become considerably less than they are today, in real terms, despite widespread expectations to the contrary. Lower import prices would mean lower domestic 
prices--very probably--and therefore reduce the viability of GCGZ production.

Second, relatively large amounts of conventional gas might be discovered, possibly in deeper formations which are gradually becoming more accessible through advancing technology. Even without the decp gas there are respectable estimates that producible U.S. resources of conventional-natural gas also can excecd $1,000 \mathrm{TCF}$. If these prove to be correct then perhaps 20 to $25 \mathrm{TCF}$ annually could be produced over the next 40-50 years from conventional sources alone. If gas from these resources is less costly to produce, then it could prevent the large-scale development of the GCGZ for perhaps $20-40$ years.

Third, the availability of existing pipelines to handle both conventional and geopressured gas can be an important aspect of the economics. As long as existing pipelines are not operated at capacity then any new production, such as that possible from the GCGZ, gets a "free ride." If, however, additional pipelines have to be built then their amortization charges must be added to the cost of production, thereby reducing the competitiveness of the GCGZ gas.

Fourth, there are unconventional sources of gas other than the geopressured methane that might provide substantial competition. These sources include many low-permeability formations (especially in Western U.S.), methane trapped in coal deposits, and methane from Devonian and other gas shales. Although each of these sources has its promoters and detractors, over the next few decades it is quite likely that one or more of them may to a limited extent provide a more economical source of gas than the GCGZ.

Fifth, because we assume that for commercial purposes oil and gas production can be combined, there are a number of potential technological competitors in synthetic fuels, including their in-situ production from shales or coal. Even now a number of promising possibilities exist for technical breakthroughs which may make synthetic fuels more competitive. Because solid fossil fuel resources are so enormous, they. could provide very strong competition unless restricted by other factors (such as costs or environmental constraints). Some technologies for synthetic fuels production exist today, and other are under active development. It secms likely that early in the $21 \mathrm{st}$ century many types of synthetic fuels plants will exist in the U.S., Canada, and other countries. Although prices of synthetic fucls arc still not expected to be competitive in the near term, this expectation could wilt 
soon after, if not before, a mature industry with advanced technology is established.*

\section{Political Pressures}

With respect to domestic politics it is impossible to know the dominant pressure groups which might exist in the U.S. 25 years or more from now. However, we can readily imagine that if a large synfuels industry comes into being that it might, under some circumstances, feel threatened by the potential for "excessive" production of geopressured methane. Certainly it is possible that if the synfuels industry becomes very large that it would resist any perceived threats from cheaper geopressured methane. Second, despite many current views to the contrary it is possible that conventional gas might still be rather abundant in the year 2000 , as was indicated above. Potential investors in longterm projects are generally nervous about the possibility of falling prices and tend to avoid marginal production facilities unless assured of long-term sales contracts or offered sufficient guarantees against possible losses. If politics preclude a significant amount of federal support for GCGZ investments, the free market may not be strong enough to provide much more than token financing prior to the 21 st century.

Finally, we cannot ignore the possibility that the antigrowth lobbies, which have recently become powerful in this country, may continue to be influential. Their influence could hinder investments in the GCGZ. Perhaps some of their expressed concerns about land subsidence or induced earthquakes could not adequately be resolved without decades of $\mathrm{R}$ and $\mathrm{D}$ experience. With political backing such concerns might enable them to restrain the commercial development of geopressured methane for many years--especially if OPEC pressures have abated. Our success scenario assumes that the true social costs of geopressured production are tolerable. That is, the legitimate concerns about the environment, the ecology, the uses of the land and the rights of the inhabitants provide problems that can be solved with time, money, and innovation without destroying economic viability. On the other hand delaying tactics by interest groups with strong ideological motivations can often create time-consuming difficulties for energy projects whether or not such tactics are "legitimate."

* Sec Chapter II of Suggestions for a Phase-II National Energy lolicy, lludson institute report 1978 . 
Although we will not explore any specific political or regulatory problems related to GCGZ production, the size. of the producible rescrves over time and the rate of production will be affected by such considerations. The wide range of outcomes in the subsequent scenarios are believed to be sufficient to straddle the potential difliculties of this kind that could arisc.

\section{Future Gas Imports}

During the last few years in both Mexico and Canada the growing potential for conventional natural gas production has great 1 y exceeded prior expectations. As a result Canada even now is considering further increases of its gas exports to the U.S., while Mexico and the United States are negotiating for the first increment of Mexican gas.

Although in any optimistic scenario both of these countries are potentially large producers, to many observers the Mexican resource appears to be unusually great. In fact some are beginning to think that the new petrolcun ficlds in southcrn Mexico may rival those of the Persian Gulf. Along with Mexico's oil production there will be considerable amounts of associated natural gas, the logical market for which exists in the United States. Although some of this gas can be used within Mexico, the amounts which are likely to be produced during the balance of the century should greatly exceed the internal Mexican requirements. It does not seem to be beyond the scope of a guardedly-optimistic development to expect that in the late $1990 \mathrm{~s}$ the Mexicans might have as much as 10 TCF to export annual1y. Canadian exports, on the other hand, are unlikely to reach such large numbers, but from 2 to 4 TCF annually is not unlikely.

If natural gas in the quantities indicated above might be imported from Mexico and Canada, and if the feasibility of such developments becomes apparent during the next several years, then it is relatively unlikely that production of geopressured gas will be able to compete on a strictly commercial basis. That is, we can expect that both Mexico and Canada would have a strong need to sell any surplus gas, for which the U.S. provides the only sensible commercial market. In particular, the bulk of the Mexican gas is likely to be priced at whatever level is necessary to enter the U.S. market. Accordingly, it should not be considered unlikely that Mexican gas will eventually enter the U.S. at or below interstate prices, currently about $\$ 2$ per MCF, but destined to grow about $3-4$ percent annually--in real terms. 
We need to ask, under such circumstances, whether the GCGZ could be or should be developed, since they would probably require some form of subsidy. The government's response is likely to be related to that part of its encrgy policy which reflects the necd for maintaining energy sccurity, or a relative degree of energy independence over the long term. Also, it would reflect the amount of the subsidy which would be required. In the Cautious l)evelopment sconario (table 1 , Section VI) we note that in the period 1985-2000, a geopressured production capability of less than .6 TCF annually is developed. If that is a valid scenario then it could be persuasively argued that, with or without the imports from Canada and Mexico, the development of the GCGZ should proceed because it could set the stage for a large 21st century production increase that is 1 ikely to become very desirable. In other words the 1985-2000 period can be viewed as the one in which this infant industry can mature. It could provide such a large potential for enhancing future U.S. energy security that it might well be deserving of a small subsidy-. say, $\$ 1$ per MCF during the initial 10-15 years--perhaps made available through tax incentives and royalty reductions.

Over the balance of this century the price of natural gas imports may well be determined by competitive sources which can be produced in the United States. Many petroleum experts have claimed that U.S. production of natural gas from conventional sources is likely to decline over this period of time even with the recent increase in interstate prices--and perhaps even with still higher prices. If so, then any long range view would see the advantages of being able to place a ceiling on the cost of gas imports, by creating a new domestic industry which could be rapidly expanded. If, during the balance of the century, we come to believe that the GCGZ will eventually be able to produce very large quantities of methane at prices of about $\$ 3.00$ per MCF (in 1978 dollars) then the early birth of a modest technological capability plus a capacity for rapid expansion could be very important. The U.S. would be better assured of its ability to negotiate reasonable long-term import contracts with its southern and northern neighbors at prices which would not exceed those for producing methane from the GCGZ, or other unconventional sources.

Thus, the potential resource in the GCGZ not only offers considerable promise for furnishing a substantial portion of our fuel needs over the long term, but also might be of considerable assistance in keeping the prices of imported fuels within a reasonable range over the mid-term (prior to 2000). Mecting both of these goils is undoubtedly fundimental in U.S. energy policy. 


\section{GEOPRESSURED ENERGY DEVELOPMENT SCENARÍOS}

A. "Cautious Development" Scenario from a Moderate Resource

To visualize the long-term development of energy from the GCGZ it is convenicnt to assume a definite quantity for the ultimate producible reserves. In this scenario that quantity is taken to be 1,000 quads of methane. By producible we mean that the price at which the methane can be cxtracted and sold (after taking credit for the commercially-extractable heat and mechanical energies in the fluid) is competitive with those of gas and oil from other sources. It is orienting, at present, to think of that price as approximately $\$ 2.50$ per MCF, in 1978 dollars.

Secondly, it is also reasonable to assume that whatever amount is correct as an ultimate projection of reserves that, initially (that is during this century), only a small amount would become available for production at a competitive price. Accordingly, we assume that the first increment of reserves is 100 quads ( 10 percent of the ultimatc total), that it can be discovered and produced with technology existing in 1985 , and that it will have been placed into the category of provenreserves by the year 2000. Existing technology implies the use of standard oil and gas drilling equipment and the application of exploration and production techniques which will emerge out of $R$ \& $D$ by 1985 .

The second increment to recoverable reserves is assumed to follow improvements in technology which become commercially available during the 2000-2010 decade and permit an additional 20 percent ( 200 quads) of the ultimate reserves to be discovered. Presumably the incremental reserves would be more difficult to produce or less attractive to seek without the advances in technology. For example, the new technology might permit smaller reservoirs to become commercial through improvements which lower drilling costs. Possibly it would involve a capability for drilling to deeper zones, and might require new equipment able to withstand the harsher environment, or new completion techniques to assure adequate production rates.

In a similar way a third reserve increment of 300 quads is assumed to become added during the decade, 2010-2020. Finally, the fourth and last increment of 400 quads is more difficult to establish and requires a 30 -year period, 2020 2050 , to be placed into commercial reserves. To recapitulate, in this scenario ultimatc reserves of 1,000 quads of methane are discovered in four phases as follows: 


$\begin{array}{lr}1985-2000, & 10 \% \\ 2000-2010, & 20 \% \\ 2010-2020, & 30 \% \\ 2020-2050, & 40 \% \\ & \quad 100 \%\end{array}$

During the 1985-2050 period fuel prices are assumed to remain in a range which allows the production of geopressured methane to be competitive. This assumption is not an obviously correct one, since we cannot state with confidence that the price of oil will remain relatively steady or gradually rise during that 15-year period. It might well decline, or oscillate over wide extremes. Many price paths are possible even though today's conventional wisdom emphasizes rising-price scenarios.

We first present a cautious scenario in which development of the geopressured zones do not receive high-priority attention after they become commercial in 1985. The resource is to be developed by private interests at a pace which they find to be appropriate. For convenience we assume that the first 10 wells are completed during 1985 and then produce, on average, 2 MMCF per day for 25 years.* In fact, this average production rate per well will be assumed in a11 of our scenarios, although in reality it would be expected to vary substantially over time if, indeed, GCGZ production becomes commercial at a11. Thus, the first 10 wells will produce methane at an annual rate of $7.3 \mathrm{BCF}$. Since, by assumption, these are reasonably profitable wells, the scenario permits the growth in development shown below in table 2. For the indicated growth the required rigs, personnel, and drilling equipment should be readily available during the 1985-2000 period.

Even with the stcady increase in drilling shown in table 2 , annual production at century's end is stil1 less than 6 ICF. The growth rate during the last few years of this century is about 10 percent. Thus the cumulative production by

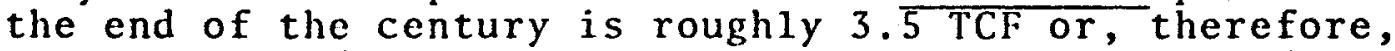
3.5 percent of the first $100-$ TCF increment of proved reserves. Sufficient reserves remain in the year 2000 for production to be increased 7 -fold to 4 TCF. At a 4 -TCF annual rate the remaining rescrves would be sufficient for about 24 years.

However, in the scenario improved technology arriving at the turn of the century allows known marginal zones to be commercially developed and/or new zones to be discovered

$\Lambda$ declining rate over timc is generally characteristic of reservoirs or particular wells. Our assumed flat rate of production is for convenience of calculation and will not materially affect the anmual production results. 


\section{Tabile 2}

\section{NATURAL GAS PRODUCTION FROM THE GULF COAST \\ GEOPRESSURED ZONES \\ CAUTIOUS DEVELOPMENT SCENARIO (1985-2000)}

DATE $\frac{\text { NUMBER OF WELLS }}{\text { COMPLETED }}$ PRODUCING WELLS PRONNUALTION $\frac{\text { CUMULATIVE }}{\text { PRODUCTION }}$

1985

10

10

7.3 BCF

1986

15

25

18

1987

20

45

33

1988

25

70

51

1989

30

100

73

1990

35

135

98

280 BCF

1991

40

175

128

1992

45

220

160

1993

50

270

197

1994

56

326

238

1,286

1995

62

388

283

1996

68

456

333

1997

75

531

388

1998

83

614

448

1999

91

705

515

2000

100

805

588

3,558 
and produced. Despite the addition of 200 quads of gas to the reserves and improved technology, because of prevailing cconomic and political considerations production only rises at a "modest" 12 percent annual rate during the decade. By 2010 gas production reaches a 1.83 lel: rate and the cumulative production will have been 15.1 I'Cl. Thus even at that date 95 percent of the discovered rescrves (300) TCF) would still be available, and "normal" growth could proceed for several years. However during the 2010-2020 decade some impressive new technology appears which, together with "anticipated" improvements in prior equipment, once, again allows the next increment of reserves ( 300 TCF) to be added. Although a substantial acceleration of the development effort becomes possible, in this Cautious scenario production increases from 2010-2020 are restrained to a 15 percent average growth rate. The increased growth rate is motivated partly by the improving efficiency from the use of new technology, and partly because growing demand for natural gas allows geopressured development to remain profitable.

In 2010, when the annual contribution from the GCGZ almost reaches 2 TCF, for the first time it becomes recognized as a significant part of total U.S. oil and gas supplics-which in the Basic (demand) Scenario was estimated to be between 50 and 70 quads. The geopressured production, although still less than 4 percent of this total, flows from an impressive growth industry. At this point in time (2010) its projected growth would give it a substantial and increasingly important role in U.S. energy supply. By 2020 production reaches 7.4 TCF annually, or roughly 10 to 15 percent of total oil and gas requirements. At 58 TCF, the cumulative production is roughly 10 percent of the reserves discovered up to that time. However, unless production increases the remaining reserves would last for another 70 years.

After 2020 the scenario (still cautious) permits growth to proceed at a 12 percent rate until the desired production level is reached. During the next 30 years further advances in technology permit the last $400-$ TCF increment to be placed in proven reserves. By the year 2030 annual production reaches $23 \mathrm{TCF}$ and about 800 of the ultimate $1,000-\mathrm{TCF}$ resource remains. AT this $23-\mathrm{TCF}$ rate production from the GCGZs could continue for another 35 years, to the year 2065 . In that cvent, if new gcopressured resources are not discovered, alternatives would be needed after 2050 to replace the anticipated decline in GCGZ production. Although a 35year proven reserve is generally larger than necessary for commercial purposes, in this scenario we simply note that because the 23-TCl: rate is roughly 30-40 percent of the expected total oil and gas demand during those decades, a substantially larger production from the GCGZ would meet stiff competition from other oil and gas sources and is less likely 
to remain profitable. Consequently, after 2030 this $23-\mathrm{TCF}$ level of production is assumed to meet the desired goal and to remain constant until the scenario ends in 2050 .

This Cautious Development Scenario demonstrates that a relatively moderate vicw of the ultimate GCGZ potential $(1,000$ TCF of methanc) ends up providing a large fraction of the demand for oil and gas in the United States during the first half of the $21 \mathrm{st}$ century. Also, during most of the scenario the rapid1y-growing reserves enable a considerable amount of confidence to be placed in the potential for accelerating production--over the rates assumed--should a compel1 ing need arise to do so. That this need does not arise in the scenario implies that fuel prices remain relatively stable and that imports do not become excessive.

\section{B. Variations in the U1timate Producible Resource}

The DOE in an earlier publication (ERDA 76-1) estimated that the expected producible gas reserves from the GCGZ might range from 500 to 2,000 quads--thus the 1,000 -quad assumption above is the geomctric center of that range. If we were to begin with the 500-quad total then the above production scenario could be identical up to the year 2030. That is, if the ultimate 500 quads became proven reserves at the same relative pace (that is, 10 percent by the year 2000; another 20 percent by the year 2010 , etc.) then the production rates described above (see figure 8) could be maintained until the year 2030 . A major shift to other energy sources would have to occur soon after that year since only a 13 year reserve from the GCGZ would still remain, if annual production stayed at 23 TCF.

If, on the other hand, the ultimate GCGZ reserves equaled the DOE's high estimate of 2,000 quads, then after the 23 TCF rate had been reached in the year 2030 , production at that level could be maintained for an additional 44 years beyond 2065-that is, until 2109. Thus, we observe that the growth depicted in this Cautious Development scenario, from 19852030 , is insensitive to the size of the producible resource, if it exceeds 500 quads. However, if it were desirable--as we expect it might be--to have a much more accelerated GCGZ development, especially during the early years, then there might be some further production restraints because of the need to maintain a reserve margin sufficient to permit this acceleration to occur (see section on Accelerated Development). 
Figure 8

"CAUTIOUS DEVELOPMENT" SCENARIO FOR GCGZ PRODUCTION, AND ALTERNATIVES FOR NON-U.S. WGZ PRODUCTION

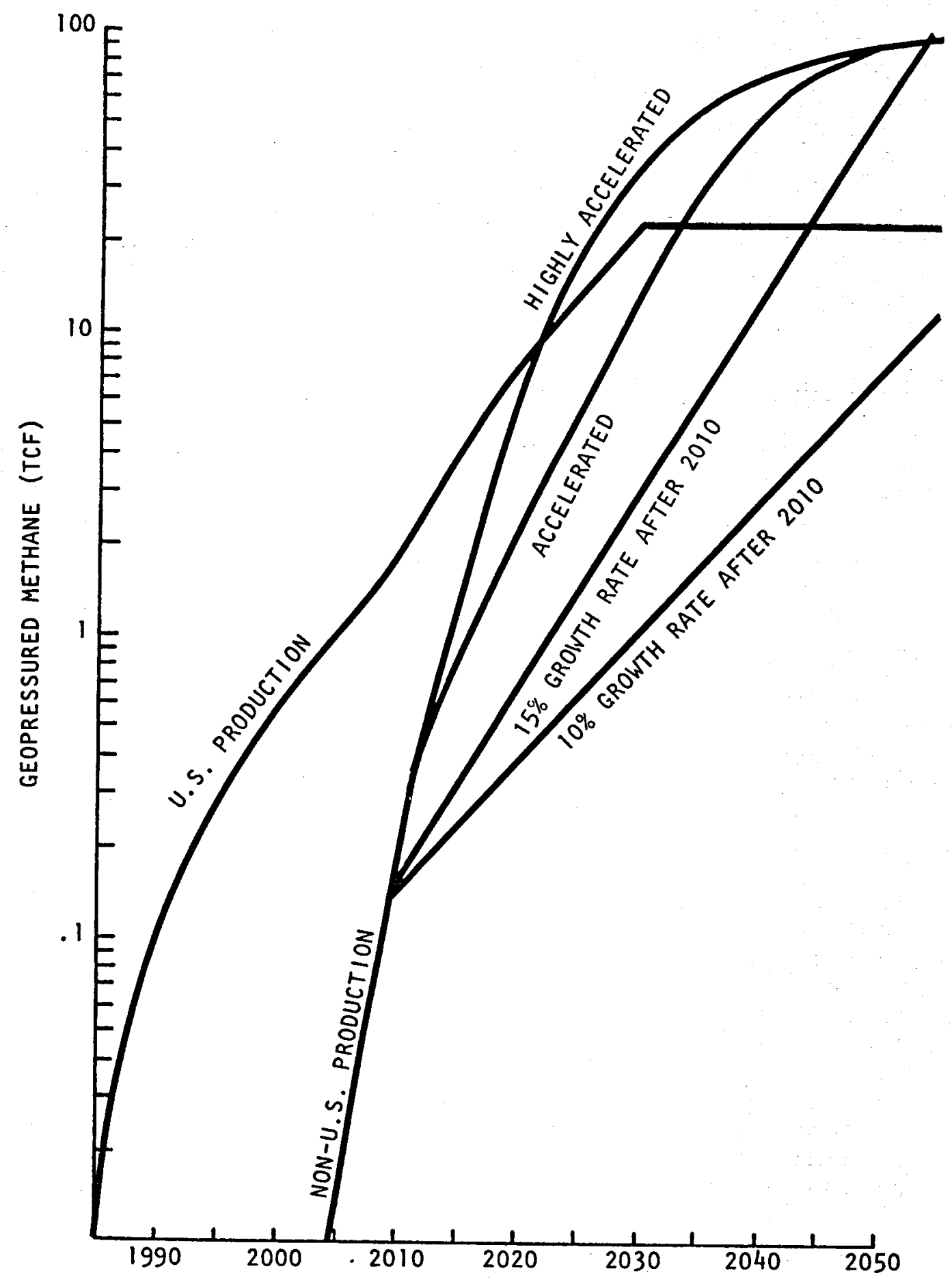


C. Worldwide Geopressured Zones (IVGZ)

Lacking an authoritative estimate we have assumed that the ultimate amount of producible geopressured methane out side the U.S. is 10 times that of the Gulf Coast Geopressured zones. On the hypothesis that, on average, geopressured methanc resources will be available roughly in proportion to the number of square miles of land in any large region, the factor of 10 is a conservative assumption. The U.S. comprises only about $1 / 17$ of the world's land area; besides, it has a considerable geopressured potential outside the Gulf Coast. Moreover, while it is likely to take decades before enough data exists to make even a rough professional estimate of the non-U.S. WGZ potential, sufficient geological information is available to indicate that geopressured formations exist in so many places around the world that it should not be too misleading at this time to claim that they will be found almost randomly located over the surface of the earth.

In any scenario in which the WGZ becomes developed, a very substantial lag behind the U.S. effort must be expected because of the near certainty that most of the available technology would derive from the experience in the U.S. Therefore any program for commercial production abroad very 1 ikely would have to follow U.S. developments. Perhaps at least as important, most geopressured production from any particular basin now seems likely to occur only after many years of conventional natural gas development. When both are possible from the same geopressured basin (as may now be expected from limited past experience) the economics is likely to favor prior conventional production. If so, during the conventional natural gas production phase much of the needed infrastructure (especially the large diameter pipelines) could be created and reduce the subsequent costs associated with transport of geopressured gas. Accordingly, we expect that any serious development. effort in the non-U.S. WGZ would be two or more decades behind that in the U.S. However, once that development begins, its growth rate could readily exceed that portrayed for the early stages of the GCGZ (table 2 and figure 8 ). In our scenario, therefore, we assume that non-U.S. production from the WGZ "begins" in the year 2005. Eventual1y their production level far exceeds that in the U.S., but not for some years after the maximum U.S. production is reached.

The rate of development of the IVGZ will depend upon the urgency of the need for gas outside the U.S. Because oil and gas demand in other countries is expected to increasc relatively faster than in the U.S. (figure 7) it is reasonable to assume that the non-U.S. world would be relatively eager to develop its geopressured capability unless other cheaper sources of gas can be found in sufficient quantity. 
The required transfer of U.S. technology, in principle, need not lag by more than 20 years initially, and somewhat less as time goes on, becausc U.S. companies are likely to be active in producing these resources. We have plotted in figure 8 both the GCGZ production resulting from our Cautious Development Scenario and four possibilitics for non-U.S. WGZ production over time-assuming a beginning in 2005 . In one projected outcome--the highly-accelerated case--the non-U.S. WGZ production passes that of the U.S. in 2022 , and becomes four times as great by 2050 . In that year the non-U.S. WGZ are producing about 90 TCF of methane per year. That production level would fill a large portion of their minimum demand or a moderate portion ( 16 percent) of the maximum demand for oil and gas that was estimated earlier (i.e., a range of 135-555 quads, after subtracting U.S. demand from world demand in 2050). If the world's total demand for oil and gas stays near the maximum of the projected range, then the WGZ contribution could continue to increase to at least 230 quads. In any event, as figure 8 shows, the protracted growth in WGZ production beginning shortly after the turn of the century could become very impressive.

The growth in non-U.S. WGZ production sccnario mentioned above is called the highly-accelerated development. A somewhat less rapid WGZ development but still an accelerated production scenario is one which restricts the growth to 20 percent annually once total production exceeds 1 TCF annually. This outcome is also shown in figure 8 , along with a moderate 15 percent and a modest 10 percent growth projection. With these constraints the crossover point (where U.S. and non-U.S. production become equal) occurs in the year 2033 and 2043 , respectively, in the accelerated and moderate cases. Of these two the 15 percent growth probably is the more realistic scenario for the $21 \mathrm{st}$ century, given our basic resource assumption; that is, one without too much optimism about continuing the long-term growth in production beyond the 21 st century.

\section{Accelerated GCGZ Development Scenario, From a Moderate Resource}

This GCGZ production scenario is based upon the same 1,000 -quad ultimate producible resource, but during the early years is associated with a greater sense of urgency than the Cautious one. Thus, after promising $R$ \& $D$ between 1978-1985 commercial production starts with 20 completed wells in 1985 . With a relatively rapid growth 760 wells are completed in the year 2000--at which timc the annual production is more than o times as great as that in the cautious scenario (sec table 3). 


\section{Tablc'3}

\begin{tabular}{|c|c|c|c|}
\hline $\begin{array}{l}\# \text { OF WELLS } \\
\text { ADDED } \\
\end{array}$ & $\begin{array}{l}\text { TOTAL } \\
\text { WELLS }\end{array}$ & $\begin{array}{c}\text { ANNUAL } \\
\text { PRODUCTION (TCF) } \\
\end{array}$ & $\begin{array}{c}\text { CUMULATIVE } \\
\text { PRODUCTION (TCF) } \\
\end{array}$ \\
\hline 20 & 20 & .015 & \\
\hline 40 & 60 & .044 & \\
\hline 70 & 130 & .095 & \\
\hline 100 & 230 & .17 & \\
\hline 140 & 370 & .27 & \\
\hline 180 & 550 & .40 & 1.0 \\
\hline 220 & 770 & .56 & \\
\hline 260. & 1030 & .75 & \\
\hline 300 & 1330 & .97 & \\
\hline 350 & 1680 & 1.23 & \\
\hline 400 & 2080 & 1.52 & 6.0 \\
\hline 460 & 2540 & 1.85 & \\
\hline 520 & 3060 & 2.23 & • \\
\hline 590 & 3650 & 2.67 & \\
\hline 670 & 4320 & 3.15 & $\cdot$ \\
\hline 760 & 5080 & 3.71 & 19.6 \\
\hline
\end{tabular}


For a GCGZ development to provide a significant energy contribution during this century, and to have a substantial geopolitical impact before the 21 st century, a rapid carly growth, such as that depicted in this Accelcrated Development scenario, is highly desirable. The outcome does not reflect a maximum cffort or crash program, which might be desirable in another context, but rather one which starts quickly and expands at a pace consistent with that expected of a dynamic long-term growth industry. It also implies that the pertinent economic, political and technological factors associated with such production from the GCGZ would be conducive to that result.

Even in this scenario, by century's end less than 20 percent of the first $100-$ TCF reserve increment has been produced. However post-2000 production is unlikely to be increased much more until new reserves are found. With the assumed discovery of the 200-TCF increment during the 2000-2010 period ample reserves would become available for a 12 percent growth rate-as in the prior scenario--but not 15 percent. Still, production can triple during the decade and reach 11 TCF in 2010. That production rate, together with a good potential for reaching the 23-TCF goal during the next decade, essentially fulfills the national encrgy objectives. At a continued 12-percent growth rate that objective is reached during 2017 .

It should be noted that an accelerated development of the GCGZ production capability will provide U.S. industry with the experience and facilities for a more rapid transfer of the technology to other nations, should this be desirable. In this scenario U.S. production increases so rapidly that it would be doubtful that the capability in other parts of the world could follow a similar path without at least a 20-year lag. Figure 9 contains a graph of the projected U.S. production; it also shows a parallel result from the non-U.S. WGZ, one that is displaced in time by 20 years but continues beyond the 23-TCF level.

In the Accelerated Production scenario it is no longer true that the feasible U.S. growth rates are relatively insensitive to the size of the producible resource base as in the prior scenario. That is, if the 1985-2000 increment in available reserves had been 50 rather than $100 \mathrm{TCF}$, then by the end of the 20 th century the reserves would have declined to about 30 TCF and, at the production rate of almost 4 TCF per year, would have a reserve production ratio of only about 8--a relatively meager ratio for a rapidly growing industry. In fact, such a small ratio almost certainly would not be feasible without changing the assumption that wells are expected to produce for about 25 years. Without that change a "sound" development of the 5080 wells shown in table 5 would require 
liguro y

ACCELERATED DEVELOPMENT SCENARIO FOR WGZ

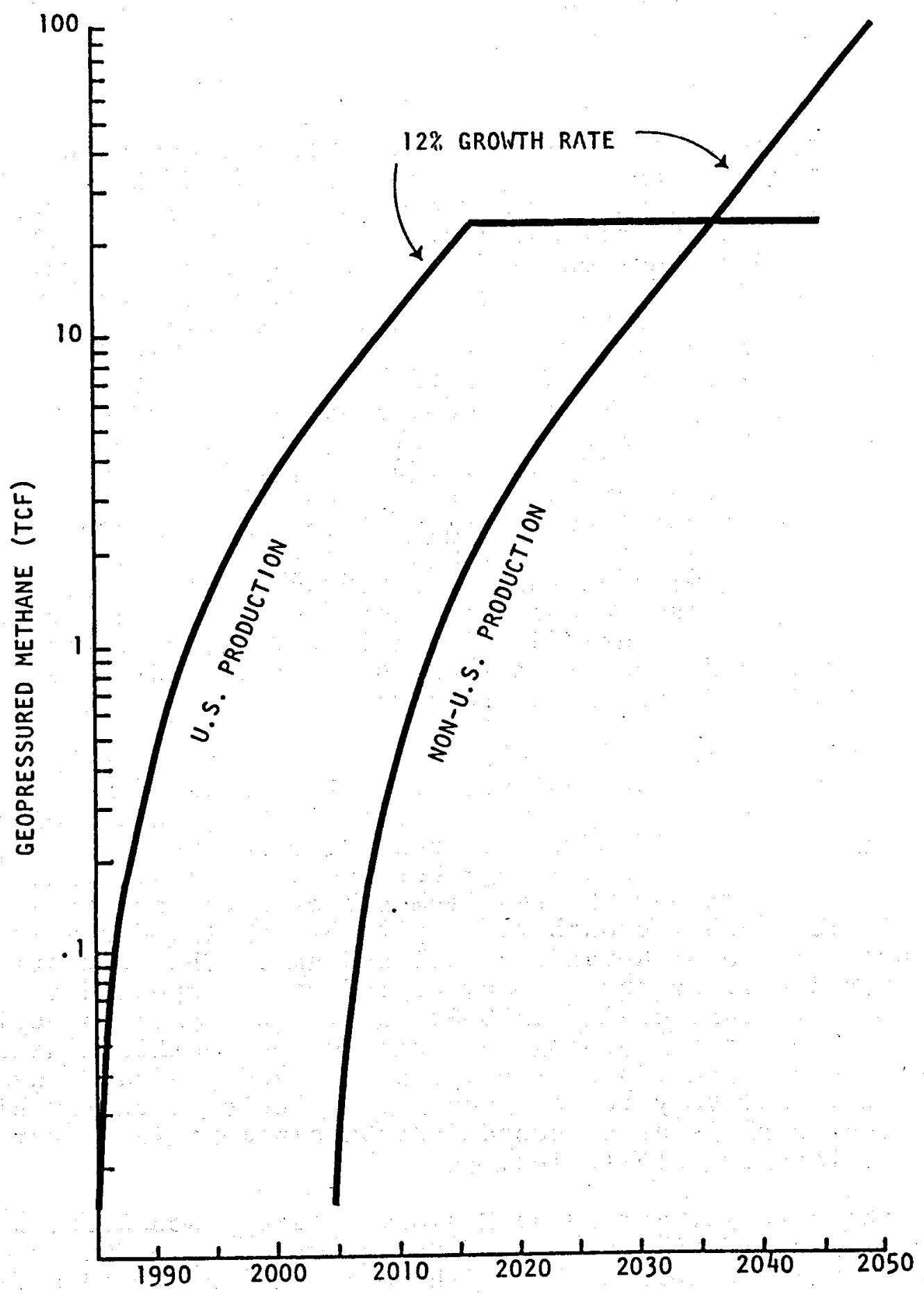


at least 70 TCFs of remaining reserves in the year 2000--a result which would be consistent only with ultimate producible reserves of at least 900 TCF, if 10 pereent of them are found during the 20 th ientury.

\section{E. GCGZ Min-Max Scenarios}

Our Moderate Resource assumption is that 1,000 quads of natural gas can be cventually produced from the GCGZ. Furthermore, we assumed that these reserves could be established by the year 2050, the primary endpoint of our discussion. Then, keeping the same production schedule, we discussed two variations of the assumed size of the ultimate resuurce-one of 500 quads, and one of 2,000 quads. Now we ask two other questions: (1) What might be a minimum resource base of significant interest to the U.S. and the world? (2) At the other extreme of a very optimistic outcome, what amount might properly be termed an enormous producible resource? Tentatively, we offer answers of 100 TCF and 10,000 TCF, respectively. This gives us the five cases which are shown below in table 4. The sizes of the first four incremental reserve discoveries are kept proportional to the ultimate reserves in each scenario except for the one with enormous $(10,000$ quad) long-term potential. In that case we not only increase the amounts of the incremental reserves, but add a fifth increment, which is discovered over an addtional fifty-year period (2050-2100) and provides 5,000 quads of proven reserves.

The "Minimum-Interest" resource, case $A$, portrays the GCGZ as ultimately capable of producing 100 quads of methane. This is roughly the encrgy equivalent of 16 billion barrels of oil, or roughly half of the current U.S. reserves. Thus, it is a resource of some interest but one which could make only a small impact on U.S. requirements over the next 50-100 years. It is roughly enough to supply between 1 and 2 years of the projected U.S. demand for oil and gas. That potential, spread over a half century or so, would not be expected to produce any significant change in U.S. energy policy or in world energy development. Assuming that production in this MinimumIntercst scenario builds up slowly, poaks, and gradually declines, it is unlikely to make much of a ripple in energy history--except perhaps as a recorded disappointment--a former high hope, largely unfulfilled.

In the parallel worldwide Minimum-Interest scenario, using the same factor of 10 (that is, 1,000 quads for the WGZ outside the U.S.), the producible methane is eyuivalent to a ficld of about 160 billion barrels--roughly the oil reserves of Saudi Arabial today. This amount of (nelg) is sufficiont to supply 


$$
-45-
$$

Table 4

FIVE BASIC SCENARIOS FOR DISCOVERY OF METHANE RESERVES IN THE GCGZ

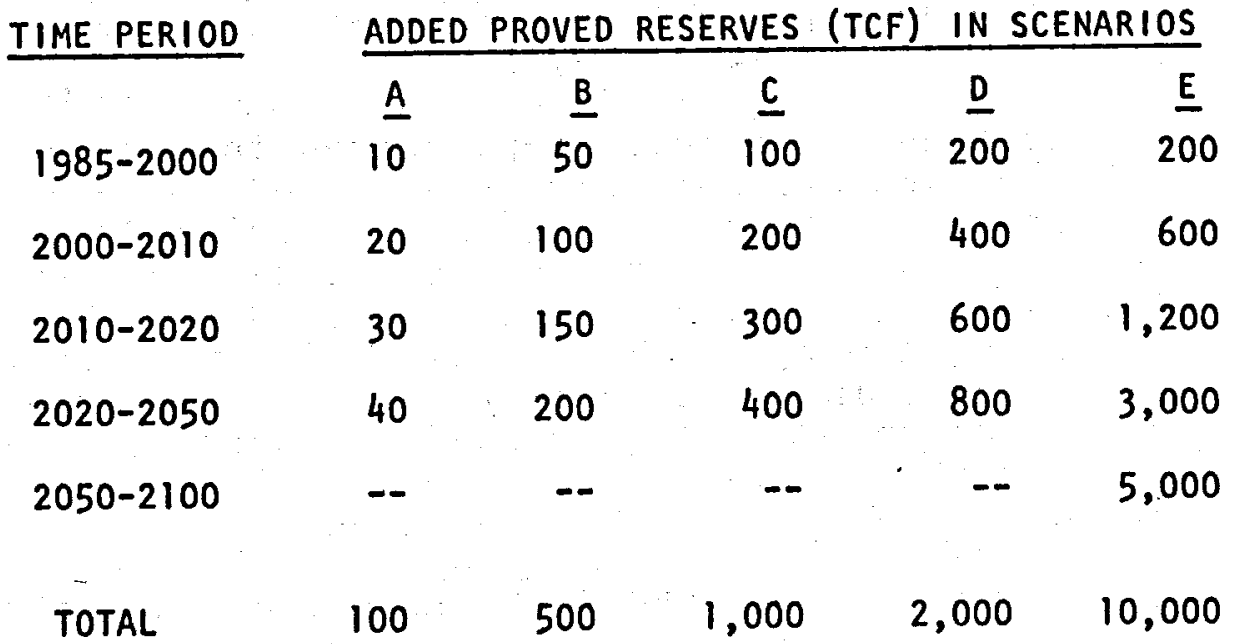


the world with oil and gas for about 6 years at its current rate of consumption. Thus, it would certainly be uscful over the long term. However, significint quantitics are unlikely to be produced during the next 20 years or more, and in any year thereafter this resource could probably supply no more than 3 percent of the world's oil and gas demand. Clearly we are contemplating an important resource but again not one likely to make a big impact in encrgy history.

The truly exciting scenario is represented in casc E. There, the GCGZ reserves are not only established in relatively large increments but, beginning in the period 20202050 , continue to be established at an average rate of 100 quads per year. Subsequently, during the next 50 years, it is determined that an additional 5,000 quads will be eventua11y producible. Thus, in addition to the large quantities of heat and mechanical energy, 10,000 quads of methane would become available to the U.S., the equivalent of 200 years of oil and gas at our present rate of consumption.

Under our assumption that the GCGZ are not unique, the implication is that the total worldwide resource would contain 100,000 quads of producible methane, an amount which appears large enough to furnish projected worldwide oil and gas requirements also for about a 200-year period. A commercial natural gas resource of this size can change the nature of the civilized world. For one thing, since methane is the cleanest-burning fossil fucl, it would substantially reduce a great number of the potential air-pollution problems which are currently associated with oil and the solid fossil fuels. Second, if this resource can be placed into reserves at rates consistent with the normal growth in demand, and if it is fairly ubiquitous in its occurence, then almost every country could soon have its own natural gas supply and therefore could eventually become about as independent of imported fuels as it chooses. This is not to say that there would not be continued trade in oil or even coal in the middle of the 21 st century. Rather, such trade would tend to be based on temporary or local economic considerations and would be unlikely to pose the major security threats currently associated with oil imports.

Also potentially very important, would be the impact of widespread use of natural gas on the long-term carbon dioxide problem, should this problem prove to be a serious one in the next century. A growing use of natural gas instead of coal and oil could reduce the injection of carbon dioxide into the atmosphere by approximately a factor of 2 and therefore roughly double the time available to meet any potential crisis due to 
growing carbon dioxide levels. If a serious carbon dioxide problem does arise in the 21 st century, without a question inany years, perhaps several decades, would be required to provide an effective worldwidc solution. Thus, if (without the postulated natural gas) the problem were destined to become severe by the year 2050--as some now expect--then it is somewhat doubtful as to whether the international system could respond adequately in so short a time. However, if by a growing emphasis on geopressured methane the critical point could be pushed to the end of the 21 st century, not only would there by the additional time to take appropriate action, but during that extra time additional technological developments could greatly increase the number of response options. Thus, if a worldwide transition must be made involving a much greater proportion of solar heating or nuclear power or the use of renewable fuels or energy from the wind and ocean, or the creation of carbon dioxide sinks etc., then without doubt the additional time should prove to be extremely valuable, if not crucial.

There is 1 ittle point in speculating excessively about whether the GCGZ might ultimately be capable of yielding 10,000 quads of methane. We briefly discussed a few such speculations earlier. At present we can only conclude that it is not impossible. If production from zones below 20,000 feet are not excluded from consideration the conclusion might be stated more positively. Thus, the enormous resource scenario can be considered as very optimistic and very unlikely, but still it cannot be ruled out completely. Also, now that the $R \& D$ is well underway the next several years may substantially. increase our ability to make a meaningful assessment of the ultimate GCGZ potential.

\section{F. A Politically Important Scenario}

(1) Early commercial GCGZ production technology is established by 1985 , at which time estimates of the ultimate (post-2000) potential reserves ranges from 500 to 2,000 quads. Initial production costs from the better reservoirs is expected to average about $\$ 2.50$ per MCF.* It can only be a matter of speculation as to whether the improvements in technology will increase rapidly enough to offset the higher cost of production from more marginal reservoirs. A wide gulf exists between the more optimistic and pessimistic projections; the optimists cxpect production costs to fal1 below $\$ 2$, the pessimists expect it to rise to over $\$ 4.00$.

${ }^{*} 11$ prices are in 1978 dollars unless otherwise stated. 
(2) In 1986 the potential for the ultimate development of the WGZs is somewhat better understood. The numbers bandied about for the size of this potential run between 2 and 20 times that of the projections for the GCGZ. It is also generally believed that the anount of non-associated conventional gas which can be produced from the same basins would be about cqual to that from the geopressured dissolved gas, but that the conventional gas would generally become available prior to the geopressured production.

(3) By 1985 OPEC prices had climbed to $\$ 18$ per barrel, roughly $\$ 3$ per MCF in gas equivalent. llowever a substantial surplus production capacity cxisted within Ol'lC and frequent discounting of the official price reflected some of their internal difficulties maintaining that price.

(4) Negotiations to reduce the possible rise in OPEC prices began during the early $1980 \mathrm{~s}$ but they had not succeeded as 1985 drew to a close. As a consequence, the U.S. announced a new energy program which, among other measures, included massive support for GCGZ production over the next 10 years. The incentives included first, a 30 -percent depletion allowance which essentially freed the production from income taxes; second, royalty-free production in any federal lands; third, a 25 percent tax credit for tangible drilling costs; and fourth, a subsidy of $\$ 1$ per MCF for completed wells with production of less than 2 MMCF per day. The announced purpose of the new federal program was the launching of a massive effort in energy alternatives that could place a long-term ceiling upon the price of imported fuels.

(5) During the closing months of 1985 , as industry responded to the incentives, 25 wells were spudded and at least 100 more were expected to be drilled in 1986 . With the government subsidies the wellhead prices were expected to become competitive with conventional gas production which at that time was about $\$ 3.00$ per MCF. The U.S. program set a goal of 5 TCF of geopressured production by the end of the century.

(6) During 1986 the increase in drilling activity, the announced investment plans of private firms in the GCGZ, and and extra $\$ 1$-billion 5-year $R$ \& $D$ budget for geopressured production were a few of the consequences of the new program that brought forth numerous predictions of declining OPEC prices over the balance of the century. Whether or not it was duc to the psychological impact of the U.S. program, by the end of 1986 it became well known that discounts in the announced price of oil up to $\$ 2$ per barrel were once more 
widely available in OPEC. Saudi Arabia remained the principal exception, but their production fell from 11 MBPD to $7.5 \mathrm{MBPD}$ during 1986. By the end of that year it was believed that even the Saudis were discounting their price by almost $\$ 1.00$ per barrel through special arrangements with the major companies who dealt with ARAMCO.

(7) By 1990 the failure of OPEC to raise prices in ine with inflation effectively reduced them to $\$ 14.50$ per barrel, or the equivalent of gas at $\$ 2.35$ per MCF. Even at those prices discounting of up to $\$ 1$ per barrel was often found out side of Saudi Arabia.

(8) OPEC requested the IEA to invite its member countries to a joint conference to take place early in 1991. This conference was to discuss the possibility of devcloping stable long-term oil prices in international trade. It was not known whether such a conference had much chance of being successful; the fear was not that prices would increase excessively, but that they might decrease precipitously and destabilize international trade once more.

The above sccnario attempts to make the point that the price of oil in international trade can only sensibly be restrained by sufficient excess capacity in conventional production or--as may eventually be true--by sufficient production of oil and gas from unconventional sources. A role for GCGZ production is indicated, with the presumption that similar roles and incentives would be available for other unconventional energy sources. The projected outcome for GCGZ production is somewhat greater than that shown earlier in the Accelerated Production Scenario--the early development is at a faster rate and the goal for the year 2000 is roughly 50 percent higher.

We emphasize the point that the disseminated knowledge of the GCGZ potential as a commercial alternative can, if belicved, become an important factor in cncrgy pricing. The announcement of federal incentives to privatc industry and the initial wave of drilling that follows, coupled with a greatly increased $R$ \& $D$ budget, might very well strongly affect the long-term expectations of all oil exporters.

It is important to note that the decline in the price of oil depicted during the next several years (1985-1990) would more than offsct the costs to the nation for hoth the production incentives and the increase in the $R$ \& $D$ budget. That is, if the U.S. were importing about 3 billion barrels a year (as it did in 1978) then the $\$ 3.50$ decline in prices, portraycd hetweon 1985 and 1990 provides about \$10 billion per yoar in reduced import costs to the nation. This 
concept, that a wel1-designed "expensive" U.S. energy program might be free, or might even have negative costs, when it is credited for its effect upon imported ruel prices, can hardly be overstated.

Unfortunately it can seldom be known, in actuality, how much any single action affects international prices. However, the relationship of prices to current or anticipated capacity surpluses can be roughly estimated. Moreover, the relative cconomic security that is experienced during periods when OPEC's prices are stable or declining slowly can be very important for worldwide prosperity. Investments in programs which help to provide that kind of security can be quite rewarding.

It is also clear that appropriate arrangements are required to avoid the disturbing economic problems which can arise if international oil prices decline rapidly, or precipitously, to levels substantially below those of production from existing marginal facilities. Worldwide economic prosperity is best served by reasonably stable energy prices. Rapidly changing ones introduce shocks into the international system of trade, shocks which in their snowballing effects can often be much more devastating than the gains or losses which might come from the change in oil prices. The above scenario ends with plans for an international conference which hopes to stabilize oil prices at a "reasonable leve1." A1though it may be desirable in principle, that outcome is deemed unlikely to occur, or to survive if it is attempted. 


\section{EVÁLUATION}

\section{A. About the Chanccs for Success}

We have constructed several scenarios, some of which might be regarded as fairly fanciful, for the production of energy--principally methanc--during the next 50-100 years from the geopressured zones of the Gulf Coast--and from similar resources in other parts of the world. If even the least of our five principal scenarios were to "come true," it would be an event similar to the discovery of a very great treasure. We have indicated some ways in which this might occur, hinted at the kind of luck that would be needed, and mentioned the nature of the skills and the technological progress that might be able to bring this treasure into reality. What might be the chances for such a treasure to actually materialize? To be rigorously honest, except to say that it is not impossible, we just don't know!

Let us suppose that, by consensus, experts would agree that, conservatively, the chances of success would be about 1 in 10 if we invested about $\$ 100$ million during the next several years--or with a more pessimistic view, perhaps $\$ 500$ million over a few decades. However if either investment should bring forth even the minimum treasure indicated in the prior scenarios, it would have a market value of more than $\$ 100$ billion; and for the more optimistic scenarios the value could be 10-100 times greater. These numbers apply. only to the geopressured geothermal resources of the Gulf Coast of the U.S.; the eventual production from similar resources in the rest of the world could be several times greater. Under these circumstances if the chances of success were actualiy 1 out of 10 we would have to deem it a marvelous investment opportunity, even if it took 20 or 30 years to commercialize. Also, we can't ignore the possibility that, with luck, commercialization might occur much earlier, perhaps even within a few years.

Also, before all of the $\$ 100-\$ 500$ million is spent it might be determined that commercial production from the GCGZ is a lost cause and the balance of the program could be cancelled. A more likely sequence of events, however, is that soon after the first test well is drilled and evaluated.that is, after about $\$ 10-\$ 20$ million is spent--a decision will be made about the timing and direction of future $R$ \& $D$. We might conclude for example that the available technology needs to be improved, or radically changed, or that we had by chance picked an inappropriate site. $\Lambda$ ter mulling over the cvidence the technical experts would offer their advice about the best next step to take, if any. 
It is possible--although unlikely--that a single failure in field experiments would be conclusive about future commercial potential. Still, after such an event a decision might be made that commercial production is substantially beyond the state of current technology. What would happen as a result of that decision? Without much question we believe that there would still be a number of interested scientists, engineers, geologists and other technical experts who would like to try to solve the important remaining problems, if practical solutions are not absolutely precluded by the evidence. They would ask the critical questions about what is needed, what might be innovated, or what we can hope to invent or discover. Experience has shown that it is often surprising how much competent professionals can accomplish if they have a decade or more in which to solve the relevant problems. Thus, assuming nearly the worst outcome for the first major experimental well, it may take about another 10 years of study, design, and innovation before another reas onable attempt can be made to locate and produce the hopedfor treasure. If the results of the new effort are again negative, perhaps, another decade or so must pass before the third attempt can be made. Thus, as long as a reasonable opportunity for establishing the treasure can be visualized that would be actively supported by dedicated competent people, it should be difficult to avoid making small incremental investments which would keep the hopes alive.

The investigative path now actually being followed may, in fact, be similar to the one just described. During the last few years the authorized budget for determining the GCGZ potential has increased from about $\$ 1$ million to approximately $\$ 29 \mathrm{milli}$ on (in fiscal 1979). Although for both technical and bureaucratic reasons recent progress has been slower than anticipated the drilling has begun at a preferred site in Texas and, during 1979, the carly field data from this program should emerge. The analysis of the new data should provide clues about the accessibility of the treasure over time and enable us to determine the next best step. The die has been cast and we must now hope for a positive result on this first round.

\section{B. An Early Success Scenario}

We wish to describe a more detailed sequence of events leading to commercial geopressured production. We begin with the Brazoria well which is being drilled even as this scenario is being written, and is destince to become the first carcfully-prepared full-scalc test of a potentially large high-volume rescrvoir. liirst, suppose that the outcome 
is reasonably successful--that is, the well yields over 2 million cubic feet of methane daily and is judged to be commercial. N1so, suppose that after two or threc years of stcady production the rescrvoir pressure remains sufficiently constant to indicatc that a commercial level of production could continue for about 20 years or more. After that, assume that two more wells are drilled a few miles from the present one, and that they too become commercial producers. How, we ask, might these results affect private entrepreneurs? While the first positive result might have becn insufficiently persuasive to doubtful observers-after a11, it could have resulted from a bit of unusual luck that is unlikely to be reproduced--that conclusion would undoubtedly be considerably shaken by two more successful commercial wells in sequence. By then, would not the more optimistic produccrs be studying the preferred sites and planning their own lirst attempts? Would not the value of land believed suitable for geopressured production have increased in price substantially? And would not a wave of excitement sweep through the oil and gas industry as a result of three geopressured successes in a row?

During this same period of time we might expect that opposition groups will also begin to arise, groups with their own special interests to protect. Their causes might include the protection of farmland, of the environment, of the ecological balance, of the health of people and animals, of our quality of life, of fishing rights, or marine life, of our future resources, of our climate, of "fair" labor practices, etc. Today any developer of a large project understands that such groups and the various regulatory agencies which are responsive to their needs must be dealt with. Obtaining a reasonable balance between the needs of the nation, the needs of the entrepreneurs, and the needs of the special interest groups is an ongoing struggle--but one which citizens usually feel is proper, when not carried to excess. The usual point of view of the entrepreneurs is that most of this struggle merely adds unnecessary expense and involves agonizing delays.

Surprisingly, perhaps, it can be observed that entrepreneurs often endure this "torture" and accept the additional costs, risks and delays, perhaps considering them an inevitable part of the political process. Unfortunately, however noble and desirable they may be separately, it is not infrequent that the goals of the various interest groups end up being in conflict. In some of the more difficult situations this process can lead to protracted hassles, in and out of court, and to repetitious hearings which sometimes make the pursuit of a project a somewhil misoliable cxporicice. Incvitably, some projects are rejected or cancelled during this process. Still, as recent exprience has shown, somehow 
$-54-$

projects "miraculously" cmerge out of this regulatory gauntlet and are eventually completed.

For the Geciz we can assume, therefore, that despite the well-known problems which are associated with the possibility of land subsidence--including some possibility of small earthquakes being set off by slippages along faults--and by the problems which might be associated with environmentally-sound disposal of the spent brines, the projects arc able to go ahead--that is, adequate solutions to these and other problems are found and implemented. We also assume that the legal problems which surround the obscure definition of, and the ownership rights to, this resource are sufficiently settled that most of the desirable land for leasing and drilling becomes available to entrepreneurs who are willing to invest in geopressured energy. Presumably by 1985 some sites would be ready for commercial drilling.

The major remaining question will not be whether the geopressured zones are commercial but rather how much energy can be produced, at what price, and over what period of time! This success scenario brings us to the five long-term out comes presented carlier, and which we think reasonably straddle the interesting range of potential production from these zones. That is, we come to the task of establishing the reserves and of improving the production outlook over time through the application of improved or more innovative techniques. That happy outcome, then, leads us back to the consideration of what happens in less successful scenarios; of what might happen if the results are largely negative--at least near the beginning.

\section{Scenarios Involving Early Failure}

Returning to the Brazoria we1l, in terms of demonstrating a commercial potential it might be a failure, or only a marginal success. Or, if it were moderately successful either or both of the next two wells could be failures or marginal. What happens then? In any of these cases, in comparison with the above scenario, the commercial outlook will have experienced a relatively severe setback. Nevertheless, as indicated earlier we would then expect to find some of the involved professionals analyzing the data, determining what went wrong, putting their heads together, and determining how best to proceed in the future. They would need to assess the situation-probably a very complex one--and determine whether any of the new data, or new information, that has been discovered is decisive in precluding further attempts to exploit the geopressured resource at that time. They would need to judge whether 
sufficient hope of success still exists, and what investments in time, manpower, and dollars are required to provide another reasonable chance of finding commercially-producible reserves.

The above experience is a common one in Nucrican jndustrial history. In petrolcum cxploration competent teams have often had repeated failures but have persisted, belicving that the chances and rewards of success were strong cnough to take the risk of failure. We know that experienced teams of dedicated, competent people can be expected to move expeditiously towards solutions of the perceived problems. Often they are reasonably able to determine the expected costs in advance. If it is a government-sponsored project, for each major step the final decision would almost always be determined by the political process. If, after an early "failure," the decision is made to continue $R$ \& $D$ for a reasonable length of time, perhaps a few years, then after monitoring the results of that endeavor a decision could again be made about attempting to commercialize the process.

Under such procedures it is difficult to conceive of any result emerging other than one which, in effect, states that "at present methane production from the GCGZ will cost approximately $\$ X$ per MCF." Since this would be an infant technology whatever the value of $X$, it would be expected to

- diminish over time. Thus if $X$, initially, were $\$ 6$ per MCF, then hope will exist that within a few years it could be reduced to $\$ 5$ or $\$ 4$ per MCF. At each step during the $R$ \& $D$ process it will be asked whether X might soon become comparable to the prices of other fuels of similar quality. As long as $X$ is too large dedicated people will generally be available to attempt to reduce $X$ by continuing the $R$ \& $D$ effort. As long as commercial viability has not been estab1 ished the government must determine whether continued support of this program is technically desirable and politically viable.

liventually two outcomes are possible. First, the costs might be reduced to the point where GCGZ production is competitive. That brings us back to onc of the success scenarios, displaced somewhat in time. However, if at some future date a decision is made to abandon the program, then clearly it would not be because the geopressured zones can't be produced, but that $X$ is too large. Also, over time it might even be found that $X$ has been reduced to a very reasonable number (say, $\$ 2$ per MCl:) and is still not commercial. That is, competing alternatives may by then have been developed so successfully, and can be produced so incepensively, that without GCGZ production the nation has become assured of a long-range supply of adequate and relatively incxpensive cnergy supplics. 
The morc successful the nation's $R$ \& $D$ program into alternative forms of energy becomes, the more likely it is that several of its "successes" may have to be dropped or "mothballed" because they would no longer be competitive. If this should happen to the effort to produce energy-from the GCG2 then it would probably be the best possible outcome for the nation. Failure, in this sense, can have a strangely positive interpretation.

In early U.S. cxperience wood gave way to coal as a primary fuel. Prior to the oil embargo coal had been gradually failing as a competitor to oil and gas. Since the embargo, coal has become one of the more promising fuels while oil and natural gas (according to some experts), through exhaustion have begun to fail as long-term compctitors. It is the conventional wisdom that, in this sense, the failure of petroleum and natural gas will continue and that these fuels gradually must be phased out of the world's energy systems; that they must be replaced eventually by renewable or inexhaustible sources; and that "temporarily" nuclear power and the solid fossil fuels--to some extent converted into liquid and gaseous ones--will bridge the gap. Whether that conventional wisdom scenario unfolds during the 21 st century, as is often visualized, or whether it is postponed for decades or centuries by the development of unconventional energy sources, such as the World's Geopressured Zones, remains to be seen. 
VIII. CONC:LUSIONS

(1) The uncertainties about the potential comnercial production over time from the GCGZ are enormous. If feasible at all, it appears that the ultimate amount of producible energy is likely to be very Targe (greater than 100 quads), if only because the resources in place are so huge.

(2) Ongoing ficld tests in Texas are the first major step towards establishing commercial feasibility, at least at presently-preferred sites, and might very well be successful. llowever, cven if such production is found to be cconomically marginal, or sub-marginal, the experience is likely to suggest an appropriate course for future $R \& D$, in pursuit of the potential treasure.

(3) The current U.S. program is aimed at commercializing the geopressured resources which can be found roughly between 10,000 and 20,000 feet. Whether or not this program succeeds, for the more distant future another huge potential may exist at greater depths--up to 40,000 feet, or more.

(4) For success scenarios the range of interesting outcomes extends from 100 to 10,000 quads of methane, ultimately producable from the GCGZ. Most of the analysis examines the effects near" the geometric center of this range--approximately 1,000 quads--and finds potentially great economic and political benefits for the U.S., and many other nations.

(5) The ultimate worldwide potential for production of resources similar to thuse of the GCGZ cannot now be estimated on a sound engineering basis. Because of the widespread occurrence of the geopressured phenomenon in hydrocarbon deposits we have assumed that the potential production from the world's geopressured resources would be about 10 times that of the GCGZ. If these resources do exist, the world geopressured production is expected to begin about 20 years after U.S. production, and eventually to rise to a much higher level.

(6) In success scenarios, the potential producible reserves could furnish a substantial fraction of the projected 21 st century requirements for fluid hydrocarbons. For the U.S. this production would probably be available soon after the year 2000; for the non-U.S. world roughly 20-30 years later. 
(7) Geopressured energy must meet competition from both conventional and unconventional sources of natural gas, as well as from other energy alternatives. A capability for producing geopressured methane at $\$ 2.00$ per MCF (in 1978 dollars) is likely to make it commercial, but still would not guarantee its long-term viability.

(8) To become commercially feasible geopressured methane, like any other major energy alternative, would have to survive the rigors of the regulatory gauntlet. The principal environmental problems that are now visible are related to the disposal of the spent brines and the possibility of land subsidence.

(9) If producible reserves of 500 quads, or more, of geopressured methane are found in the GCGZ during the next 50 years, it would not only greatly assist the U.S. in meeting its future energy needs but could also help to place a long-term ceiling on international fuel prices. 